\title{
Household Income, Demand, and Saving: Deriving Macro Data with Micro Data Concepts
}

\author{
Barry Z. Cynamon and Steven M. Fazzari*
}

\section{Working Paper No. 13}

\begin{abstract}
We develop adjustments to align the NIPA measures of key household flows with cash flow concepts that better reflect household budgets and demand. The adjustments significantly change important macroeconomic time series and give different perspective on household spending and saving. Furthermore, household income aggregated from micro data sets like the CPS, SCF, and PSID differs significantly from NIPA personal income. But the micro survey data likely reflect cash flow concepts rather than NIPA imputations. Indeed the adjusted cash flow measure of income eliminates most of the shortfall of CPS, SCF, and PSID of CPS income relative to NIPA household income.

JEL Codes: No. E01, E21

* Cynamon: Visiting Scholar at the Federal Reserve Bank of St. Louis Center for Household Financial Stability and Research Associate at the Weidenbaum Center, Washington University (bcynamon@wustl.edu); Fazzari: Professor of Economics, Washington University in St. Louis and Associate Director of the Weidenbaum Center, Washington University (fazz@wustl.edu).
\end{abstract}


One explanation for the Great Recession advanced by many economists is that a historic collapse of household demand was to blame for the recession itself and the slow recovery. This interpretation is supported by a casual look at major components of demand from the National Income and Product Accounts (NIPAs): personal consumption expenditure (PCE) and residential construction fell significantly more in the Great Recession than in other postwar U.S. business cycles. ${ }^{1}$ Much analysis of the Great Recession explores the reasons for the remarkable decline in these components.

Any analysis of the way in which spending and borrowing of the household sector led to the Great Recession, however, must confront two related measurement problems. First, one must identify the macroeconomic data that best corresponds to the concept studied. The PCE variable in the NIPAs is the most commonly used measure of aggregate consumption, but, as we discuss here, it may not be an accurate measure of household expenditures that generate demand for market-produced goods and services. Second, in order to understand the channels through which shocks are transmitted through the household sector, it is necessary to observe household-level behavior. Disaggregated data is essential because heterogeneity between households is a key aspect of many interesting theories, and because a data set with thousands of households contains thousands of observations of responses to a given historical episode rather than the single data point provided by the national accounts. To test hypotheses about how a collapse in household spending caused by household access to credit led to macroeconomic crisis, requires micro data linking the balance sheets and spending of individual households. Thus, while aggregate data are

\footnotetext{
${ }^{1}$ The ratio of PCE to disposable personal income fell 3.9 percentage points from 2005 to 2008 (annual data). The next largest declines since 1948 were 3.6 (1949-1953) and 2.8 (1979-1982). The decline in residential construction as a share of GDP from 2005 to 2011 of 3.9 percentage points dwarfs the next largest postwar decline of 2.5 (19801982).
} 
necessary for understanding the macroeconomic significance of phenomena, they are not sufficient for diagnosing their causes.

The methods used by the Bureau of Economic Analysis (BEA) to construct the NIPAs tend to obscure the income, demand, and saving cash flows actually generated by the household sector. First, the "personal sector" consists of more than households. As described in the NIPA Guidebook, it "consists of individuals, nonprofit institutions that primarily serve households, private noninsured welfare funds, and private trust funds" (p. 5). Second, the BEA adds many items to disposable personal income (DPI) that households never perceive as cash income (employer contributions for Social Security, for example). Perhaps more important, the BEA treatment of construction and consumption of owner-occupied housing obscures the actual demand created by the housing sector because of the attempt to estimate the service flow of the housing stock and include this imputation in PCE. While this approach makes sense if one wishes to measure the utility generated by owner-occupied housing, implicit rent that home owners pay to themselves adds neither to the market demand for current production nor to the income home owners have to spend on newly produced consumption goods. In contrast to the implicit rental value of owner-occupied housing, construction of new homes for sale to the household sector clearly generates demand for newly produced output that motivates production and employs factors of production. Residential construction is included in NIPA measures of demand, but appears as investment, conceptually linked more closely to spending on new capital goods and structures by businesses than to the household sector that purchases the newly built single-family homes. For this reason, there is some double counting in the NIPA measures. Houses are counted as investment output when they are constructed, and these same houses are treated as generating consumption output over time as their owners obtain services from them. 
In addition to potential conceptual issues with the macroeconomic data, there are potentially severe shortcomings associated with the correspondence between macro householdsector variables and the available microeconomic data. Four of the most widely used microeconomic data sets are the U.S. Census Bureau's Current Population Survey (CPS), the Federal Reserve Board's Survey of Consumer Finances (SCF), the University of Michigan Institute for Social Research's Panel Study of Income Dynamics (PSID), and the Bureau of Labor Statistics' Consumer Expenditure Survey (CE). Each of these surveys has its own strengths and weaknesses, but they all have a disappointing record in matching the national accounts after aggregation to the U.S. household level based on appropriate survey weights. On income, Katz (2012, p. 2) claims that the CPS and the NIPAs "give different portraits of the nation's economic performance during the last several decades." On consumption, Carroll (2012) argues "the CE survey has serious and growing deficiencies (in some categories of spending, the survey's estimate falls short of NIPA data by amounts ranging up to 50 percent), it is almost the only (microeconomic) game in town for these questions." One of the primary difficulties in testing the magnitudes of the impact of various household behaviors on the U.S. economy is the pervasive doubt in the research community that the available microeconomic data sets are truly representative of the U.S. household sector, and the key test of external validity is comparison to the measures from the national accounts.

This paper takes aim at the two measurement problems that constrain research on the channels of transmission for credit, income, and spending shocks in the U.S. household sector: (1) the poor correspondence between NIPA aggregate measures and appropriately weighted microeconomic data and (2) the conceptual differences between NIPA measures of household income and spending that cause these variables to deviate from measures of household-sector 
cash flows. We meet these twin objectives by creating new macro series for the U.S. household sector - using only publicly available NIPA data - that conforms the "macro data" to a "micro concept." The primary guiding principle for the "micro concept" is that we measure only marketbased cash transactions. These are the items that households would identify when queried about their income and spending in the survey instruments used to produce micro-level data sets. Our secondary guiding principle is to differentiate between demand and non-demand expenditures of the household sector, where the former are defined as the exchange of cash for newly produced final goods and services. The adjustments we propose eliminate imputed consumption items in NIPA PCE that do not generate cash flows for businesses. We adjust DPI to correspond to the cash flows households actually receive and can choose to deploy as spending or saving. We also integrate the construction of new owner-occupied homes into the household sector demand measure in a consistent way. By adhering to the two guiding principles, we generate a measure of the demand coming from the household sector and the income spent at the discretion of households available to pay for that demand; and we find that these measures match the corresponding measures from the micro data sets much better than do the standard NIPA measures, because they reflect the actual cash receipts and expenditures of households.

As shown by Fixler and Johnson (2012), no two data sets chosen from among the CPS, the NIPA, the Congressional Budget Office, and the IRS Statistics of Income conform to exactly the same concept of income. Fixler and Johnson (2012) work on methods to adjust the CPS to match the NIPA. Katz (2012) presents methods similar to ours for adjusting the NIPA to match the CPS. Bosworth et al. (2007) adjusts NIPA income to match the SCF and CPS. All three of those efforts focus exclusively on income. Since consumption and saving are also crucial for macroeconomic analysis, it is valuable to extend these studies by adjusting the entire NIPA 
household account to a micro concept while preserving the identities that link income, expenditure, and saving.

We chose to follow Katz (2012) in modifying the NIPA household flows to a micro concept rather than adjusting a single survey to better match the NIPA conventions for two reasons. First, adjusting the NIPAs allows for comparison to all micro data sets. Second, although the NIPAs are the most widely used and cited measures of the U.S. economy they are not necessarily the appropriate measure for all purposes. As Ruser, Pilot, and Nelson (2004) and Fixler and Johnson (2012) have shown, there is no single correct measure even of such an important quantity as household income. Perozek and Reinsdorf (2002) and Guidolin and La Jeunesse (2007) make a similar point regarding the measurement of household saving. In order to do effective research, the right definition needs to be used — certainly when comparing between data sets (e.g. CPS and NIPA) but also for interpreting different theories about the economy. We argue here that the adjusted measures are more useful than standard NIPA measures of the household sector for some purposes, particularly for understanding the magnitude of changes in household demand and the accumulation (or, more accurately, decumulation) of financial saving.

The adjustments we propose change important aspects of macro fluctuations in the household sector. Our measure of adjusted household demand relative to adjusted household income rose somewhat more than NIPA PCE to DPI in the years prior to the Great Recession and the adjusted measure declines much more during the downturn. Our methods also show a much greater decline in various measures of the adjusted personal saving rate from the middle 1980s to the eve of the Great Recession, compared with the widely discussed NIPA personal saving rate. 
In section II, we discuss the overarching framework that guides our adjustments to the NIPAs. In section III, we describe the details of the adjustments and the motivating logic for our proposed changes. In section IV, we evaluate the success of our adjustments in aligning the macro data with the micro data. In section $\mathrm{V}$, we present a variety of statistics to show why the adjustments matter for the way that we understand the aggregate behavior of the U.S. household sector. We conclude in section VI.

\section{Measurement Objectives and Overview of the Adjustments}

The methods that the BEA uses to construct the NIPAs are designed to provide "a comprehensive measure of economic activity" (Bureau of Economics Analysis, 2013, page 4). Measuring comprehensive economic activity, however, may not be consistent with the way in which households perceive their economic lives, and it is not the necessarily the same thing as measuring the demand for goods and services. The adjustments proposed here are designed to define measures that reflect the actual cash flows under the control of households and how the household sector as a whole recycles these cash flows into demand and saving. The objective that motivates the measures proposed here, therefore, is different from that of the BEA and our proposals should not be viewed as criticisms of the approach used in the NIPAs.

All the detailed adjustments described in the next section respect a basic accounting identity that links income to its disposition:

$$
\begin{gathered}
\text { Disposable } \\
\text { Income }
\end{gathered}=\text { Consumption }+ \text { Investment }+ \text { Transfers }+\begin{gathered}
\text { Financial } \\
\text { Saving. }
\end{gathered}
$$

Disposable income is net of income taxes from all levels of government. ${ }^{2}$ It includes cash inflows to the household sector from labor compensation, capital income, and transfers from other sectors, including transfers from government. Consumption consists of demand for final

\footnotetext{
${ }^{2}$ Sales taxes are part of consumption. Property taxes are discussed in more detail in section III.
} 
goods and services. Household investment is the accumulation of newly produced real assets on the household sector's balance sheet. For our purposes, we limit household investment to new construction of owner-occupied housing. ${ }^{3}$ Transfers are expenditures of households that do not purchase final output, including interest payments. Financial saving is a residual that could be defined as income not spent on consumption, investment, or transfers. If expenditures exceed disposable income financial saving will be negative. Financial saving is the net accumulation of claims by the household sector on other parts of the national and global economy. Following the BEA, we use the term outlays to describe the sum of all household cash expenditures:

$$
\text { Outlays }=\text { Consumption }+\begin{gathered}
\text { Household } \\
\text { Investment }+\begin{array}{l}
\text { Household } \\
\text { Transfers }
\end{array}
\end{gathered}
$$

Household demand is the purchase of all final goods and services by the household sector:

$$
\begin{gathered}
\text { Household } \\
\text { Demand }
\end{gathered}=\text { Consumption }+ \text { Investment, }
$$

and we define total household saving as:

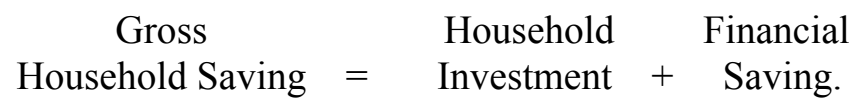

This saving concept is labeled "gross" because it is a cash flow measure that does not adjust for home depreciation. This definition differs somewhat from the BEA definition of personal saving because of the treatment of residential construction, which we discuss in detail in section III.

The NIPA data series that are the starting point for our adjustments satisfy equation 1, but some explanation is called for. There is no household investment component in the NIPAs. All residential construction of owner-occupied and tenant-occupied housing is included in the

\footnotetext{
${ }^{3}$ One might include the new production consumer durables in household investment, as in the U.S. Flow of Funds accounts, but we follow the BEA convention of including durables goods, except housing, in consumption.
} 
investment sector in the NIPAs. For this reason, equation 3 becomes degenerate in the NIPAs with household demand equal to consumption (PCE). Furthermore, NIPA personal saving is defined as the residual from NIPA DPI after subtracting PCE and personal transfers. Most important for our purposes, the NIPA concepts for all variables that appear in equations 1 through 4 include significant non-cash components, both additions and subtractions, that cause the measures of income available for disposition and expenditures to deviate from the cash flow measures that would be recognized in household budgets, would be reported by households in survey instruments, and would constitute the revenues received by businesses that produce output to meet household demand. To clearly differentiate the adjusted cash flow measures we propose from standard NIPA concept we add "adjusted" in front of any variable that refers to an adjusted cash flow concept, such as "adjusted household demand" or "adjusted gross household saving."

[Figure 1 Approximately Here]

The adjustments can be significant. For example, 2011 NIPA disposable income is $\$ 11.5$ trillion while our adjusted disposable income is $\$ 8.8$ trillion, $23 \%$ less than the standard measure. The NIPA consumption measure for 2011 is $\$ 10.7$ trillion while our adjusted household demand in 2011 is $28 \%$ lower at $\$ 7.7$ trillion. Figure 1 shows standard and adjusted measures of key household sector variables on a real, per capita basis. These simple comparisons suggest the potential importance of the adjustments that we propose, but they reflect different definitional concepts and so they can be somewhat misleading. More interesting implications of these adjustments can be seen from comparing ratios of demand or saving to disposable income across time, which we describe in section V. First, however, we explain the logic of the individual adjustments that we propose. 


\section{Detailed Adjustments}

Table 1 summarizes in detail the adjustments we make to obtain cash flow measures for the key variables described in equations 1 through 3 . Individual adjustments are described in double-entry form in the following rows, showing how each adjustment affects the major household financial flows in equation 1 . The double entries assure that the accounting identity from equation 1 holds before and after each individual adjustment. For each adjustment item, the table specifies the source of the data in the NIPA tables (table number and line number) necessary to make the adjustment. The table provides sample values for each adjustment from 2011 to provide an idea of the magnitude of each item.

In a few cases, we propose moving items out of demand created by the household sector that nonetheless should be counted in aggregate demand. In these cases, the items lead to an entry in the "Other Demand" column in the table, as will be discussed below.

\section{A. Adjustments for Owner-Occupied Housing}

The most important and economically significant adjustments we propose change the treatment of owner-occupied housing to reflect the actual demand for newly produced housing and eliminate imputed income flows that would never appear in conventional household budget measures (or in survey data that asks households to report such measures).

The BEA treats the service flow of owner-occupied housing (i.e., the value the owner receives from use of the house) as a source of implicit rental income for homeowners (owners' equivalent rent) and the consumption of housing as implicit rent paid by the home-owning household to itself. Thus, the NIPA definitions raise measures of both household income and household consumption relative to what cash accounting familiar to the typical household would 
imply. ${ }^{4}$ But implicit rental income cannot be used for spending on market-produced goods and services; it is in no sense relevant for a household's budget as usually conceived. And the imputed consumption arising from imputed homeowners' rent is not a demand for anything produced for sale on the market. Indeed, when people consume the service flows from existing durable goods — such as cars, appliances, and even art — they are not demanding new production. There is no attempt in the NIPAs to measure service flows of non-housing durables. Automobiles and other non-housing durables are included in consumption and final demand measures when they are produced and sold. It is therefore somewhat inconsistent for the NIPAs to estimate housing consumption as a service flow in the definition of final demand. One could view this inconsistency differently from the approach we take in this paper and argue that NIPA measures should try to incorporate service flows, rather than purchases, for other durables, particularly automobiles. ${ }^{5}$ The appropriate measurement concept depends on the objective. Service flow measures from durables capture the utility created on a period-by-period basis. But we are interested in measuring cash flows and demand which implies that a purchase measure is the appropriate concept. We therefore adjust the NIPA data to remove non-cash rent of homeowners from consumption and their implicit rent from disposable income.

Section 1 of table 1 describes the adjustments that address these issues for owneroccupied housing. The five lines in this section (rows 1a through 1e) can be interpreted together as the total effect of adjustment for owner-occupied housing but we describe each adjustment separately with the double-entry approach.

\footnotetext{
${ }^{4}$ The spending and income components do not exactly offset. The rental spending attributed to homeowners is the full amount of the estimated rent they could receive if they rented their homes in their local markets. The rental income is the difference between this rent and cash expenses for maintenance, interest, insurance, taxes, etc. and a non-cash deduction for depreciation.

${ }^{5}$ This is the approach taken in construction of the alternative saving measure produced from the Federal Reserve's Flow of Funds accounts.
} 
The largest component is the implicit rent that the NIPAs treat as paid from homeowners to themselves (row 1a). We subtract this item from PCE, reducing consumption demand. To maintain the identity from equation 1 we also reduce disposable income by the same amount. The income adjustment should be viewed as eliminating the revenues (but not the costs) of the implicit rental business that the BEA approach constructs for a homeowner. Of course, if an owner-occupied home were, in fact, rented instead of owned, the landlord would need to spend some of the rental revenue to pay costs to maintain and operate the home. These purchases would create demand for new production. The BEA treats such costs as intermediate inputs to the implicit rental business. ${ }^{6}$ Because our approach eliminates the total implicit rental revenue in row 1a, we add the cost of maintenance and operation back to demand in row $1 \mathrm{~b}$. This adjustment to demand is intuitive: when we stop thinking of owning a home as creating an implicit rental business, we treat the purchase of goods and services for operating the home as normal consumption demand. The necessary adjustment to DPI implied by row $1 \mathrm{~b}$, however, is less intuitive. In the NIPA accounts, the creation of an implicit rental business for homeowners leads the BEA to treat intermediate inputs like a business cost of production, so intermediate inputs by themselves reduce the profit of the imputed business. If one eliminates intermediate input expenses in isolation, that raises income.

A numerical example illustrates the logic. Suppose that the implicit rent for an owneroccupied house is $\$ 2,000$ per month and the household pays $\$ 300$ per month in maintenance and operating costs (assume for the moment that there are no other costs associated with the home). The NIPA approach measures $\$ 2,000$ of PCE for the implicit rental value of the home which becomes revenue to the implicit rental business. But the income to the rental business is reduced

\footnotetext{
${ }^{6}$ The intuition is that the full value of the home is reflected in the rent, which is the value of the final consumption. But it takes some intermediate inputs to produce that final output. The logic is analogous to any business producing a final good or service using inputs purchased from other businesses.
} 
by the $\$ 300$ expenditure on intermediate goods. The net effect on income of the combined revenues and costs is $\$ 1,700$. The adjustments in table 1 eliminate this fictitious business. In our adjusted measure, the $\$ 2,000$ of implicit rent is not demand but the operating and maintenance expenditures do create demand. In this example, rows $1 \mathrm{a}$ and $1 \mathrm{~b}$ together would reduce personal consumption demand by $\$ 1,700$. Furthermore, the $\$ 1,700$ of DPI that the NIPAs impute to the household does not exist, which is removed by the sum of lines 1a and $1 \mathrm{~b}$ in the DPI column.

Row 1c of table 1 adjusts for mortgage interest. The logic of the positive sign in the DPI column follows from the explanation of the intermediate inputs adjustment to DPI explained above. The BEA treats mortgage interest as an expense to the imputed homeowner rental business. It is therefore deducted from the rental business income and, other things equal, reduces DPI. Because our adjustments eliminate the imputed business, we eliminate this cost deduction by adding mortgage interest back to DPI. But interest expense clearly is an important household cash flow for households who have mortgages. Unlike maintenance and operating costs, however, mortgage interest payments do not create demand for newly produced output; instead they are transfers is from borrowers to lenders. Therefore, to balance the elimination of the mortgage interest deduction from the NIPA definition of DPI we add mortgage interest to personal transfers. This adjustment leads to a treatment of mortgage interest that aligns much better with the typical way households perceive their finances: mortgage interest is not a deduction from income but it is part of households' cash outlays.

It is interesting to note that the structure of the NIPA personal income and saving accounts implicitly recognizes the role of interest as a transfer because all household interest payments, except those on mortgages, are treated just like the "personal transfer" category in the NIPAs (see NIPA table 2.1, especially lines 27 through 34). Interest payments on non-mortgage 
debt are considered a non-consumption part of personal outlays. The logic for treating mortgage interest differently is because of the objective in the NIPAs to attribute imputed income to homeowners from renting to themselves, an objective that our adjustments are designed to eliminate. In our adjusted measures, mortgage interest is treated like all other interest payments by households.

Row $1 \mathrm{~d}$ of table 1 shows the adjustment for depreciation of owner-occupied housing. As is the case for GDP and national income in the aggregate, the output measure is "gross" with no deduction for depreciation while the income measure is net of depreciation. Again, depreciation is treated like an expense to the implicit rental business created for homeowners in the NIPAs, so eliminating it raises DPI, holding everything else constant. To balance this adjustment requires an increase in one of the other terms from equation 1. Depreciation does not create cash outlays; it is neither consumption nor a transfer. By eliminating the non-cash deduction from income, this adjustment, by itself, is balanced by an increase in household financial saving.

Some reflection explains the intuition for the rise in saving from eliminating the depreciation of owner-occupied homes. According to the NIPA concepts, the value of the housing asset declines by the amount of estimated depreciation. If one thinks of saving as the change in wealth, then depreciation lowers saving holding other household cash flows equal. Our financial saving concept, however, is a cash flow measure, and it should not be affected by a non-cash expense like depreciation. Furthermore, these adjustments help clarify the difference between the BEA personal saving concept and our gross saving measure defined in equation 4 above. Because household investment, i.e., residential construction, is not considered an outlay of the household sector in the NIPA accounts it is not a deduction from disposable income in the calculation of personal saving. Therefore, residential construction in the NIPAs is, implicitly, 
personal saving and lumped in with financial saving. The definitions that we propose have the advantage of distinguishing the part of gross saving that is the accumulation of financial claims on other sectors from the accumulation of real assets that are unlikely to be sold to other sectors.

Summing the adjustments in rows 1 a through $1 \mathrm{~d}$ of table 1 eliminates the imputed demand and income that the BEA creates with its treatment of owner-occupied housing as an implicit business. ${ }^{7}$ Disposable income is somewhat lower because the imputed "profit" from homeownership has been removed. The effect is not negligible, reducing 2011 disposable personal income by $3.1 \%$ (row 1 a from table 1 less the sum of rows $1 \mathrm{~b}, 1 \mathrm{c}$, and $1 \mathrm{~d}$ as a share of NIPA DPI). Removing imputed owner's rent less spending on intermediate inputs (row 1a less 1b) from consumption, however, has a more substantial effect, reducing personal consumption expenditures by $9.7 \%$ in 2011 . Although adjusting the measure of aggregate output is not the primary objective of this paper, it is also interesting to recognize that removing implicit rent net of intermediate costs reduces GDP, in 2011 by a non-trivial $6.9 \%$.

The adjustments discussed so far reduce demand that the NIPA attributes to the household sector. But owner-occupied housing certainly creates demand for current production over and above operating and maintenance costs. The demand effect comes when homes are built and sold or when they are renovated. These expenditures directly create demand, production, and jobs. Of course, these items add to demand in the NIPAs because they are treated as investment spending, lumped together with business equipment, structures, and inventories. For our purposes it is more appropriate to link the demand for new homes to the

\footnotetext{
${ }^{7}$ In principle, we should also include an adjustment for taxes on housing, primarily property taxes. These taxes are also treated as an expense in the computation of implicit rental income for owner-occupied housing. This adjustment would eliminate the rental business expense and increase personal taxes, leaving disposable personal income unchanged. We begin our adjustments with DPI and therefore do not identify the tax adjustment separately. If one wanted to measure pre-tax personal income in a way consistent with the adjustments proposed here, however, the tax adjustment would be necessary.
} 
household sector than to the business sector. ${ }^{8}$ It is the incomes of households that must pay for housing. Of course, much of this payment is often deferred as households borrow for such a major purchase. But that deferral is no different conceptually from households borrowing to pay for a car, for education, for a vacation, etc. The purchase is what creates demand. Our approach to residential construction treats housing consistently with all non-housing purchases in the economy. ${ }^{9}$

Row 1 e of table 1 provides the detail for the residential construction adjustment. ${ }^{10}$ This item is clearly an addition to demand emanating from the household sector. We define this component of demand as household investment to recognize the importance of housing as part of household wealth. (It is not an addition to GDP because the demand is simply transferred from the investment sector to the personal sector.) It may be more surprising to see the reduction in financial saving in row 1e. The key to understanding this entry is to recognize the importance of the word "financial" in this definition of saving. This saving concept represents claims accumulated by the household sector on other parts of the economy that are mediated through financial markets. An addition to the housing stock is not saving in this sense, although it clearly represents the accumulation of a valuable asset. Therefore, holding other things equal, particularly disposable income, greater residential construction reduces the financial saving of the household sector. Another way to look at this issue, perhaps somewhat mechanically, is to

\footnotetext{
${ }^{8}$ In an extensive survey of related issues, Van Treeck and Sturn (2012, page 10) also recognize that residential investment should be integrated with the household sector.

${ }^{9}$ One difference remains between our treatment of residential construction and other consumer durables. Consumption or demand for non-housing durables can differ from production of these items (in either direction) with the difference reflected in inventory changes. We do not have data for inventories of newly constructed houses. The residential construction measure used here is new homes produced rather than new homes sold.

${ }^{10}$ We take the data from NIPA table 7.12 that breaks out owner-occupied construction. NIPA table 5.4.5, however, provides more detail about what is included in total residential construction. In 2011, improvements were $46 \%$ of residential investment. This share was inflated by the housing bust, but even in the boom years prior to 2008, improvements were over $20 \%$ of residential investment. Brokers' commissions are also included in residential investment and accounted for $14 \%$ to $17 \%$ of total residential investment in recent years. The commission figures seem high until one recognizes that commissions include sale of both new and existing structures.
} 
think of spending on a new home as an "outlay." Saving is defined as the difference between disposable income and outlays. If the purchase of an additional home is an outlay, which must be the case, then the conventional definition of saving must fall holding disposable income constant. We return to this issue in section $\mathrm{V}$ where we consider alternative definitions of saving in detail.

[Figure 2 Approximately Here]

Figure 2 provides some perspective on the effect of the housing adjustments. It shows the ratio of single-family residential construction (which we add to household demand) to imputed homeowner rent net of intermediate goods (which we delete from household demand). The ratio was very high following World War 2, during which there was a boom in owner-occupied home construction. By the mid 1960s, the ratio reached levels in the neighborhood of $60 \%$ that appear normal outside of housing boom/bust cycles such as the one experienced in the past decade.

\section{B. Adjustments to Imputed Value of Free Financial Services}

The BEA imputes interest income to the household sector that families never see as a cash flow. The imputations include interest earned on property/casualty and life insurance reserves. They also include the foregone interest on bank deposits because the BEA treats the "free" banking services received on deposit accounts as income in kind to households (see Katz, 2012, page 21). These imputations are in addition to monetary interest actually paid to households by financial institutions, which we leave unchanged.

The adjustments are described in section 2 of table 1 . As shown in row $2 \mathrm{a}$, we remove all imputed interest to households from disposable income. Holding all other items constant, this adjustment reduces household saving. But there are two further adjustments that offset a substantial part of this effect on saving. The imputed interest on bank deposits is also treated in the NIPAs as the cost of financial services that households purchase from the bank. These 
financial services are included in NIPA PCE. Of course, this is not a cash expenditure and we remove it from our cash flow measure of consumption demand. There are separate items in the NIPAs for imputed banking services provided to depositors and borrowers, as shown in rows $2 \mathrm{~b}$ and $2 \mathrm{c}$ of table 1 . These adjustments by themselves reduce consumption and they increase financial saving.

The net effect of all three adjustments in section 2 of table 1 is to reduce both disposable income and consumption. The adjustments reduce the measure of household saving because interest on insurance reserves is subtracted from DPI but does not affect demand. The reduction is saving is not trivial. In 2011 these adjustments reduce financial saving by about $1.7 \%$ of NIPA DPI. Most of this effect is due to interest on reserves of life insurance companies.

\section{Pension and Retirement Saving Adjustments}

The treatment of pension and retirement saving plans presents both conceptual and data challenges. Among the most important reasons for personal financial saving is to provide funds for retirement. To the extent that saving in retirement plans meets this need, it could be viewed as a perfect substitute for personal saving outside of a designated retirement plan. But even defined contribution plans have various requirements for participation, restrictions on the use of funds, and differences in vesting that make them different from voluntary cash saving by households out of their disposable income. Defined benefit plans are even more removed from household saving.

In principle we would prefer to treat defined contribution and defined benefit plans differently. Conceptually, funds flowing into defined contribution plans, and the capital income received on balances in these plans, seem like saving to the household. And when funds are withdrawn from such plans to pay for consumption in retirement this seems like dissaving. In 
contrast, funding of defined benefit plans is the responsibility of employers and seems largely external to the household. As discussed by Gale and Sabelhaus (1999) the pension benefit for the employee's household occurs when the benefit is granted (and vested), even though the saving to fund it occurs as the employer allocates funds to its pension reserves. The effect on household income from a defined benefit plan occurs most obviously when benefits are paid, much like Social Security.

Despite the conceptual difference between defined-benefit and defined-contribution plans, we cannot implement different treatment between them from public NIPA data. The benefits paid by pension and profit-sharing plans are not separated by defined benefit and defined contribution (see NIPA table 6.11). With this limitation of the data, we treat all pensions on a cash flow transfer basis similar to Social Security. Contributions to plans from either employer or employee are not counted as disposable income. Pension benefits add to DPI when they are paid to the household sector from any source, again like the case of Social Security. Excluding pension saving from our baseline definition of financial saving likely leads our measure to understate the funds that households are putting away for retirement, but note that this understatement is substantially offset in the aggregate by treating pension and retirement benefits as part of disposable income rather than dissaving. We return to this issue in the discussion of saving rates later in this article. In any case, these adjustments are important to match the aggregate data to the cash flow accounting that likely lies behind household survey response in microeconomic data.

The adjustments are described in section 3 of table 1 . Removing contributions to retirement plans and capital income on plan balances from the NIPA DPI reduces both DPI and financial saving. We adjust for both employer and employee contributions since both will be 
used to pay benefits and the funding of benefits cannot be divided according to the source of the contribution. Again, this treatment is entirely symmetric to Social Security. While the NIPAs provide employee contribution data for publicly administered government employee plans, no information is available for private employee contributions. We estimate employee contributions to private plans by assuming that the ratio of employee to employer contributions in the private plans is the same as this ratio for the government plans.

We must also estimate the capital income earned on pension and retirement plan assets. Following Katz (2012), we compute an estimated rate of return on these assets from the life insurance industry, which should have a similar portfolio structure. The estimated rate of return is the imputed interest earned on life insurance reserves (line 46 of NIPA table 7.11) divided by the total financial assets of life insurance companies (from the Flow of Funds Z1 release, table L.115, line 1). This rate is then applied to total pension reserves (sum of line 1 from each of the Flow of Funds Z1 tables: L.116, L.117, and L.118) to estimate the capital income on pension and retirement funds. Removing this income from the household sector reduces disposable income and also reduces financial saving.

Finally, we add the benefits paid by pension and retirement plans to their beneficiaries. As row $3 \mathrm{e}$ shows in table 1, this adjustment raises DPI and financial saving. It therefore offsets, in large part, the deductions made by removing plan contributions and capital income from DPI and saving. But the net effect of the pension-retirement adjustments cannot be ignored. They reduced adjusted DPI by $2.8 \%$ in 2011 .

Section 4 of table 1 presents conceptually identical adjustments for workers' compensation. As is the case of pensions, we eliminate the payments by employers (premiums in 
this case) from income and saving but add in benefits received to income and saving. These adjustments are included for consistency, but their net effect is negligible.

\section{Adjustments for Medical Insurance and Medical Payments}

Medical spending is a significant and rising part of the national economy. In the NIPAs, health care production lands almost exclusively in the household sector despite the fact that much of it is paid for by private and government insurance programs. Expenditures for medical care are considered household spending in PCE, regardless of who pays for these services, and insurance premiums are added to DPI even if they never become part of household cash flows.

First consider the effect of private insurance. The BEA treats premiums paid by employers as "supplements to wages and salaries" that are part of DPI and any medical services paid for by this insurance are part of PCE in the household sector. Of course, this is not the way employer-subsidized health insurance affects the cash flows of households. While some employers may provide information to employees about the cost of insurance purchased on their behalf, employer payments for insurance do not affect cash flow coming into the household.

Similarly, when the household has medical costs, the deductible, co-payments, or any uncovered expense creates a negative household cash flow. But the part of the medical bill paid by insurance never enters the household's cash budget.

Our adjustments summarized in row 5a of table 1 adjust household DPI and expenditure to put medical expenditure on a cash flow basis. The group insurance premiums paid by employers are removed from DPI. ${ }^{11}$ The transaction on the other side of equation 1 that balances the DPI adjustment is somewhat subtle and involves consideration of what insurance premiums

\footnotetext{
${ }^{11}$ Line 35 of NIPA table 6.11 that provides the source data for the adjustment summarized in row 5 a of our table 1 also includes some life insurance premiums, but more than $95 \%$ of the total group insurance wage supplements has been for medical insurance since 1985 .
} 
actually pay for. In a direct sense, premiums purchase insurance. ${ }^{12}$ The funds received by insurance companies pay for the administrative costs and profits of the insurance company plus the medical services that the insurance company pays for on behalf of its policyholders. In either case, these items are part of PCE. ${ }^{13}$ Because we are interested in measuring demand that comes from households, not business making purchases on behalf of their employees, we remove the expenditure for health insurance paid for by employers from PCE so that our adjusted household demand concept contains only what households actually purchase. Note that this adjustment implicitly leaves the household's out-of-pocket spending on medical care as part of PCE and it does not affect the BEA treatment of insurance premiums actually paid by households.

The adjustments for group insurance payments in line 5a are similar to those for imputed homeowners' rent in line 1a; both adjustments have the same sign entries in the DPI and household demand columns. But there is an important difference between implicit rent and the explicit payments for group insurance. Implicit rent is not a cash flow transaction in any sense; as discussed above it creates no demand for newly produced goods and services. Payments to an insurance company to cover the costs of insurance and the benefits paid are clearly cash flow transactions that create demand for final services produced either by the insurance or the health care industries, even though this demand is not part of our definition of household demand. It is for this reason that table 1 shows a plus sign in the "Other Demand" column of row 5a. While we remove the demand created by employer group insurance payments from our definition of

\footnotetext{
${ }^{12}$ Many large firms and organizations are self-insured. But that really does not change the analysis that follows. In fact, self-insurance programs are usually intermediated by an insurance company.

${ }^{13}$ Some qualification to this statement is in order because insurance companies, or self-insured employers, may accumulate or draw from claim reserves in a given year which could make total premiums received somewhat larger or smaller than the demand for final services produced. Our approach assumes that premiums are equal to the cost of insurance plus claims paid in the aggregate, which we think is reasonable for the economy as a whole, especially over time. Any deviations from this assumption on a year-to-year basis are not likely important for the measurement purposes described in this paper.
} 
household demand, it remains part of aggregate demand. Because our focus is on the household sector, we do not need to specify the source sector for the other demand category.

Adjustments for government health insurance follow a similar logic. In the NIPAs, government payments for medical care through Medicare, Medicaid, and a very small amount for military beneficiaries are treated as income to the household sector. But the households whose medical costs are covered in these programs do not see the payments by the government to their health providers as a cash inflow in any sense. Furthermore, households do not see the expenditure from these government programs as their discretionary consumption. For these reasons we remove these items from both DPI and household demand (rows 5b, 5c, and 5d of table 1). As in the case of private group insurance, however, the spending financed by government health care remains part of aggregate demand, and therefore these items add to the other demand category.

\section{E. Adjustments to Remove Non-Profit Economic Activity from the Household Sector}

The BEA includes the relatively small, but non-trivial, economic activities of the nonprofit institutions that serve households (NPISH) in the household sector. To focus on household demand, income, and saving, we remove the items associated with non-profits, as described in section 6 of table 1 . Rows $6 a, 6 b$, and $6 \mathrm{c}$ remove explicit non-profit incomes from household DPI. Other things equal, these adjustments also reduce household financial saving. Rental income and expenditure is also imputed for non-profits in the NIPAs, and these items are removed from our adjusted measures as described in row $6 \mathrm{~d}$. Note that this adjustment leads to a net reduction in demand for the same reasons discussed previously for owner-occupied housing.

The NPISH sector receives transfers from both business and government that are counted as part of NIPA DPI. Eliminating these relatively small items (rows 6e and 6f) reduces 
disposable income and financial saving. Households also make transfers (most likely in the form of voluntary contributions) to the NPISH sector. Because the BEA consolidates NPISH and household units in the NIPAs, these transfers do not affect NIPA measures of DPI or personal transfers; they are intra-sector in the NIPAs. To meet our objectives, however, we pull NPISH activities out of the household sector which causes household-NPISH transfers to cross a sectoral boundary. For that reason, we add transfers from households to the NPISH units as a personal transfer and balance this adjustment by reducing household financial saving (row $6 \mathrm{~g}$ ). But of course, transfers come the other way, from non-profits to households, which increases disposable income and financial saving (row 6h).

Finally, the NPISH sector engages in productive activity. Some of this production is sold on the market to the household sector and represents demand created by the household sector for newly produced output. This activity is included in PCE and should remain there. But some part of NPISH production is not sold to households (consider the administration costs of grants from non-profits, for example). This output is treated as consumption of non-profits and is included in NIPA PCE. Because it is not household demand, we remove it from adjusted demand, which other things equal increases household financial saving. As in the case of medical services paid by insurance, however, even though we remove NPISH consumption from household demand, it remains part of aggregate demand, as indicated by the plus sign in the other demand column of row $6 \mathrm{i}$ in table 1.

Isolation of the NPISH sector from households has a non-trivial effect on adjusted PCE in the household sector (3.7\% in 2011). But it has little effect on household saving because the expenditures of the NPISH sector largely offset the cash flows the sector receives. 


\section{F. Miscellaneous Adjustments}

Section 7 of table 1 describes a large number of miscellaneous adjustment. With the exception of the capital consumption adjustment, these items have trivial magnitudes but are included for conceptual completeness.

Items consumed in kind provided by employers and farms are treated as PCE, and their value is added to DPI in the NIPAs. The income imputed for in-kind items is clearly not household cash flow nor is the demand for them based on financial choices made by the household sector. We therefore remove them from both adjusted PCE and household demand (rows 7 a through $7 d$ ).

Because the household sector includes proprietors' income, some non-cash NIPA items primarily associated with the business sector appear in the household accounts as well. None of the items in rows $7 \mathrm{f}$ through $7 \mathrm{i}$ represent cash flows for the household sector. The inventory valuation adjustment is designed to eliminate cash profits or losses due to the effect of inflation on the nominal value of inventories. The capital consumption adjustment arises because the BEA uses different depreciation rules from the accounting principles that generate business income. These are non-cash adjustments made to the NIPAs, so we effectively return the NIPAs to a cash basis by removing them. The trivial "margin on owner-built" housing likely represents non-cash profits imputed to home improvements made by owners.

Small subsidies and fringe benefits are removed from the accounts as described in rows $7 \mathrm{j}$ through 71. Employer payments for property/casualty insurance are treated like employer payments for medical insurance discussed above. We treat energy subsidies symmetrically. Rental subsidies in this category are removed as well. All these items are negligible. 


\section{G. Summary}

The final row of table 1 presents the adjusted measures of the main variables for 2011 . The adjustment can obviously be quite significant. Our measure of after-tax cash income households have to allocate to spending, investment, transfers, and financial saving is $26 \%$ lower than NIPA disposable personal income. Adjusted PCE is $31 \%$ lower than the NIPA values, although a more meaningful comparison is likely between the sum of adjusted PCE and household investment to NIPA PCE. This is because construction of owner-occupied homes in our adjusted measures replaces the owners' rent category in NIPA PCE. Even this comparison shows dramatic differences: adjusted PCE plus household investment is $28 \%$ lower than NIPA PCE in 2011.

Our adjusted measure of household transfers is more than three times larger than the NIPA personal transfer figure. About two thirds of the difference is due to our cash treatment of mortgage interest. In the adjusted measures, mortgage interest payments by homeowners are an outlay, the way any household would think of them, while the BEA deducts mortgage interest as a deduction from the implicit rental business income it impute to homeowners.

The adjusted measure of financial saving is almost $\$ 700$ billion lower than NIPA personal saving. The adjustments are easily large enough to push financial saving negative. NIPA personal saving and adjusted financial saving are not directly comparable for a variety of reasons that we discuss further in section V.B. But our adjusted concept corresponds to what a typical household would think of as putting income at its disposal away for future use. Our results show that this way of defining saving can be very different from the NIPA personal saving concept. 
In the subsequent sections we explore in more depth how these adjustments affect the way we relate micro data on household finances to the aggregate and on how our understanding of the aggregate economy changes with the adjusted measures.

\section{Comparing NIPA and Adjusted Macro Measures with Micro Data Sources}

This section considers how the adjusted macro measures described in section III correspond to related variables constructed from appropriately weighted microeconomic data sources for the household sector. The hypothesis is that out cash flow macro measures should close the gap between the NIPA data and variables based on micro surveys.

The Current Population Survey (CPS) administered by the Bureau of the Census since 1942 is the primary source of labor force statistics in the U.S. Currently, a representative sample of about 60,000 households are interviewed each month. Using weights provided with the survey, one can generate national data estimates from the CPS. Each household is interviewed for four consecutive months one year and the same four calendar months the following year, for a total of eight months. The CPS sample attempts to represent the civilian, non-institutional population of the U.S. by using a probability sample to select housing units. ${ }^{14}$ Each March, the CPS includes supplemental questions asking about income received the previous year. Those data were the basis of a study by Katz (2012) attempting to reconcile the CPS and BEA measures of household income, which we follow.

Per capita money income in the CPS is reported in current dollars on an annual basis, so the other measures are annual as well. Additionally, Census money income is a pre-tax measure,

\footnotetext{
${ }^{14}$ Members of the armed forces who live in off-base housing or on base with their families are included in the March CPS, but persons in the military who reside in military barracks are excluded. Institutionalized persons, such as residents of old age homes, inmates in prisons, and patients in mental institutions, are excluded from the survey (King et al. 2010). The mean income among the service members may exceed the per capita income of the CPS population, while the mean income among the prison inmates, elderly in nursing homes, and patients in mental institutions is probably less than that of the CPS sample. Consequently, the impact of the difference in sample could lead to error in either direction.
} 
so the NIPA and adjusted measures are on a pre-tax basis as well. ${ }^{15}$ All are deflated with the PCE deflator. The average of the ratio of real per capita CPS money income to real per capita NIPA personal income is $74.4 \%$ over the period $1969-2011$, while the average ratio using our new adjusted measure is $90.3 \% .{ }^{16}$ The adjustments that transform NIPA personal income to adjusted household income eliminate about two thirds of the gap between the average level of the NIPA and CPS income measures. Panel A of figure 3 plots all three series and the much greater conformity of the CPS figures to our adjusted income measure is immediately evident. This finding confirms our hypothesis that the adjusted measures correspond more closely to the way that households actually perceive their finances.

The Survey of Consumer Finances (SCF) sponsored by the Federal Reserve Board is conducted every three years to provide data on the financial behavior of U.S. families. The SCF gathers detailed information about household balance sheets, income, demographic characteristics, and use of financial institutions. The SCF base sample is representative of the U.S. population, while an additional sample obtains extra observations of rich families in order to get a more precise signal about this small group that holds a disproportionate share of the nation's wealth. Though the first wave of the SCF was conducted in 1962, most researchers use the triennial surveys from 1989 and onward due to the stability of the survey definitions during that time period.

\footnotetext{
${ }^{15}$ In the case of the adjusted measure of before-tax income, rather than simply starting with adjusted household disposable income and adding personal current taxes, we also add property taxes on owner occupied housing (Table 7.12 , line 135), which is omitted from NIPA personal income entirely and therefore also excluded from personal current taxes. This extra adjustment pushes up our adjusted measure of income, increasing the remaining gap, but also makes before-tax adjusted income conceptually consistent with our main income measure, which is after-tax. ${ }^{16}$ The gap between adjusted and CPS income in figure 3 widened noticeably in the early 2000s. One possible explanation is under-reporting of high incomes in the CPS coupled with rising income share at the top of the distribution. This explanation is consistent with the larger drop of adjusted income during the Great Recession compared with the drop in CPS income.
} 
The SCF reports mean family income for the year preceding each of its triennial waves from 1989-2010. Income in the SCF is pre-tax and includes realized capital gains. The SCF also reports the number of families represented by the survey, so an estimate of aggregate per capita income implied by the SCF is derived by multiplying the mean family income by the number of families represented by the survey to get an aggregate income number and then dividing by the U.S. mid-year population from the NIPAs. In order to put the NIPA and our adjusted income measures on the same basis, taxes and realized capital gains (as reported by the Congressional Budget Office, 2013) are added in real dollars.

The ratio of real per capita SCF income to real per capita NIPA personal income averages $78.7 \%$ across the eight observations from 1988-2009, while the average ratio using the new adjusted measure is $97.7 \%$. The adjustments that transform NIPA personal income to adjusted household income eliminate almost $90 \%$ of the gap between the average level of the NIPA and SCF income measures. Panel B of figure 3 shows the striking correspondence between the adjusted and SCF income measures, as compared with the standard NIPA measure.

The Panel Study of Income Dynamics (PSID) is a longitudinal study of a representative sample of U.S. individuals and their family units that began in 1968. Sixty percent of the initial 4,800 surveyed households belong to a cross-national sample from the 48 contiguous states, while the other portion is a national sample of low-income families from the Survey of Economic Opportunity. The survey was conducted annually through 1997 and biennially thereafter. The most recent wave of the PSID (2011) includes close to 9,000 households. In addition to extensive data on household demographics and income, the PSID also has detailed data on household wealth holdings as a part of wealth supplements in 1984, 1989, 1994, and 1999 onward. The wealth data include information on households' stock and bond holdings, the 
value of their checking and savings accounts, retirement accounts, vehicles, other (non-primary) real estate, and any business or farm equity the household might have. In addition, the wealth supplements report households' non-collateralized debt liabilities.

From the PSID, we use real, pre-tax income including realized capital gains. In order to put the NIPA and our adjusted income measures on the same basis taxes are added and we also add realized capital gains as reported by the Congressional Budget Office (2013). Again, all series are expressed per capital in real 2005 dollars. The ratio of real per capita PSID income to real per capita NIPA disposable personal income averages $82.6 \%$ across the 20 observations from 1984-2010, while the average ratio using the adjusted measure is $101.8 \%$. Panel $\mathrm{C}$ of figure 3 shows again that the correspondence is much closer between the adjusted and the PSID per capita income figures than between the PSID and the NIPA figures (dotted observations after 1997 reflect the fact that PSID surveys shifted from annual to biannual after that date).

We are also interested in how the adjustments proposed here cause aggregate household expenditure and saving measures to correspond with micro measurement concepts. This comparison is much more difficult than for income, however, because none of the micro surveys contain direct measures of aggregate consumption or outlays. We undertake one comparison using the methods developed in Cooper (2010) to estimate personal outlays from the PSID. That method uses changes in balance sheets between waves of the PSID that included the supplemental wealth questions. Consequently, the expenditures derived by this method cover periods of five years each from 1984 to 1998 and periods of two years each from 1999-2010. ${ }^{17}$ We calculated the NIPA and adjusted measures by averaging per capita, real outlays over the same time periods. Figure 4 presents the results. The new measure of adjusted per capita real

\footnotetext{
${ }^{17}$ Originally, the PSID was administered every year and the wealth module was administered once every five years starting in 1984. After 1997, when the PSID was changed to a biennial schedule, the wealth module was included in every wave.
} 
outlays tracks the PSID estimates much more closely than the NIPA outlay measure. The ratio of real per capita PSID income to real per capita NIPA disposable personal income averages $83.4 \%$ across the nine observations from 1984-2010, while the average ratio using the adjusted measure is $97.5 \%$.

We did not prepare income or expenditure data from the Consumer Expenditure Survey (CE) for comparison to our adjusted measures, because the $\mathrm{CE}$ is currently undergoing a multiyear re-design process to address known sampling and underreporting issues (Sabelhaus, et al. 2013). The primary issue with the CE data is underreporting of both income and consumption combined with an increase over time in the severity of the underreporting of consumption, as documented in Slesnick (1992), Laitner and Silverman (2005), Heathcote, Perri and Violante (2010), and Aguiar and Hurst (2013). As the underreporting has increased in severity for consumption but not for income, the aggregate saving rate implied by the $\mathrm{CE}$ data has increased during a time period when the national accounts have shown it in decline.

\section{Comparing Adjusted and NIPA Macro Measures}

The results in section IV imply that the adjusted macroeconomic measures we propose in section III do indeed correspond more closely to the micro concepts reflected in household survey data. Our adjusted aggregate measures more accurately track the way that households perceive their income and spending, and therefore, by extension, also their saving, compared with standard NIPA measures. This finding provides support for our argument that it is useful to measure aggregate household activity with the adjusted cash flow concepts as a complement to the BEA approach used in the NIPA. In this section, we explore how the different macro concepts lead to different perspectives on aggregate economic activity in the household sector. 


\section{A. Household Demand}

The adjustments proposed here are detailed and the logic behind them is often somewhat subtle. The magnitude of individual adjustments can be large, but many of them offset to some extent. On net, our cash flow measures of both household disposable income and demand for newly produced output are substantially below corresponding NIPA concepts. On average, demand is reduced somewhat less than disposable income (15\% for demand and $18 \%$ for disposable income from 1948 through 2011). The ratios of both adjusted demand and adjusted household disposable income to the corresponding NIPA variable decline almost linearly from 1948 to 1990 , reflecting a variety of factors, including the rising importance of employer benefits in total employee compensation. By the end of the sample, the adjustments for demand and income amount to about a quarter of the corresponding NIPA measures.

Figure 5 presents three measures of household spending relative to income. The bottom series is adjusted consumption relative to adjusted disposable income which is always below the ratio of standard NIPA PCE to DPI. This outcome is not surprising considering that adjusted consumption excludes the substantial imputed homeowners' rent that is part of NIPA PCE. But

of course, the construction of owner-occupied housing adds to demand. When we add residential construction of single-family homes to adjusted consumption we obtain a ratio of household demand to adjusted income that is usually substantially higher than the ratio of NIPA PCE to DPI.

[Figure 5 Approximately Here]

The behavior of the series in figure 5 over time is also of interest. All three series trend downward from 1948 through the early 1970s, although the trend is more pronounced in the adjusted household demand series. This was a strong period for the aggregate economy even 
though the share of household cash flow recycled to direct demand for goods and services was declining. This was also a period of strong income growth across the income distribution in which household demand was evidently driven by income rather than a rising spending rate. Clearly, good economic performance in the U.S. does not require households to spend a rising share of their income.

As is widely recognized, however, the downward trend in the spending rate was reversed beginning in the early 1980s. In other work (Cynamon and Fazzari, 2008 updated in Cynamon and Fazzari 2013) we labeled the period from the mid 1980s up until the Great Recession the "Consumer Age" due to the significant rise in the standard ratio of NIPA PCE to disposable income. Figure 5 shows that the adjusted measures increased more from the middle 1980s through the early 2000s. It is also clearer from the adjusted measure that the increase in the spending rate mostly took place prior to the period of the greatest excesses of the housing boom. The adjusted demand-income ratio actually peaks in 1999, although the local peak in 2005 is nearly as high. Furthermore, the adjusted consumption-income ratio, which excludes both residential construction and implicit rent on owner-occupied housing, also rises sharply from the early 1980 s through 2000 . There is no doubt that household finances became more fragile in the years immediately prior to the Great Recession, but the adjusted data make it especially clear that the household spending boom was not just about building new houses and its roots go back at least to the early $1980 \mathrm{~s}$, as argued in our earlier work and that of many others. ${ }^{18}$

The most striking differences between the NIPA and adjusted ratios in figure 5 are the severity of the drop in the household spending rates during every recession. In particular, the collapse in adjusted household demand during both the early 1980s and the Great Recession is magnified significantly by our adjustment. The reason for these rather dramatic differences is no

\footnotetext{
${ }^{18}$ See Palley (2002) and Brown (2004), for example.
} 
mystery: we have integrated the volatile residential construction sector with non-housing consumption. The early 1980s recession and the Great Recession were driven in large part by historic declines in residential construction. As discussed in the previous section, however, the adjustments required to define the new measures consistently involve much more than simply "adding in" residential construction. We must replace the housing imputations in the NIPA data with residential construction with careful attention to detail to avoid double counting of the housing component.

The adjustments we propose also affect the definition of GDP. The magnitude of the adjustment effect on GDP is smaller than on household demand because some components that we remove from household demand (notably medical care paid for by insurance) remain in the "other demand" category of table $1 .{ }^{19}$ But our adjustments reduce our measure of the value of the final value of goods and services produced for market sale relative to the standard GDP measure. The effect is due mostly to the housing adjustments, although eliminating the imputed value of financial services has a non-negligible effect. The size of the GDP adjustment grows over time due to the increasing value of imputed owners' rent relative to owner-occupied residential construction. Nominal adjusted GDP is about 5\% lower than NIPA GDP at the beginning of the sample. By 2011, adjusted GDP is more than 9\% below the official measure.

Because of the deeper decline in residential construction than implicit rent during recessions, all recessions during the data period are more severe according to the adjusted GDP measures. The largest effects are $-0.5 \%$ for both $1973-1975$ and $1981-82$, and $-0.8 \%$ for $2007-$ 2009.

\footnotetext{
${ }^{19}$ There are also some imputed components of GDP that we do not adjust, because they are not part of the household accounts. Our adjustments touch the three largest of the four major imputations in U.S. GDP. The fourth, consumption of general government fixed capital, accounts for less than $2 \%$ of GDP.
} 
It is also interesting to explore the significant effect of third-party health care spending on the macroeconomic trends of the household sector. Figure 6 presents three measures of spending relative to total output. The series that usually is the highest in figure 6 is NIPA PCE as a share of the standard measure of GDP. As discussed earlier, NIPA PCE includes health care spending by government and employers; that spending is not determined by households' direct budgetary choices. The series in figure 6 that tracks the trend of the standard PCE-GDP ratio rather closely (until the Great Recession) is our adjusted measure household demand plus the non-household part of medical care spending, as a share of adjusted GDP. According to both of these measures, household spending has a clear positive trend as a share of GDP for most of the period covered by our data. The bottom line, however, is our adjusted household demand as a share of adjusted GDP that excludes the part of medical care spending not controlled directly by households. According to this measure, the share of spending in adjusted GDP does not rise over most of the sample. This observation leads to an intriguing conclusion that the much discussed rise in household spending as a share of GDP over recent decades was generated by the rapid rise in health care spending paid for by government and employers.

[Figure 6 Approximately Here]

\section{B. Household Outlays and Saving}

Figure 7 presents household outlays to disposable income; again including both the official NIPA data and our adjusted series. While the time-series pattern of the outlay rate is very similar to the demand rates from figure 5, the differences between the NIPA data and our adjusted approach is more pronounced for outlays. The adjusted outlay rate ranges between 7 and 15 percentage points higher than the official rate. The difference between outlays and demand arises from transfers out of the household sector. The BEA includes two categories of 
these transfers: personal transfers (such as funds sent to foreign nationals) and personal interest payments excluding mortgage interest on owner-occupied houses. As discussed earlier, mortgage interest in NIPA is treated as a deduction from the income homeowners pay to themselves rather than as a transfer. Our approach eliminates the concept of the homeowner as an implicit rental business and puts mortgage interest together with the other interest payments paid by households. Even though it is added to both outlays and income, the addition of mortgage interest is the primary reason that our measure of outlays to disposable income is greater than the NIPA measure.

[Figure 7 Approximately Here]

Figure 8 provides more detail about the composition of transfers; it shows the three primary transfer components as a share of adjusted household disposable income. Mortgage interest is much greater than the two components of transfers identified by the BEA. It is not surprising that mortgage interest payments rose sharply during the period of accelerating inflation and increasing nominal interest rates in the 1970s and early 1980s. It may be surprising, however, that this trend was not reversed as nominal mortgage interest rates fell to historic lows in the early 2000s. We infer that it was the rapid increase in mortgage debt outstanding that offset the fall in nominal interest rates during the Consumer Age, as is discussed in Cynamon and Fazzari $(2008,2013)$.

[Figure 8 Approximately Here]

As figure 7 shows, the adjusted measure of household outlays relative to adjusted disposable income implies that households paid out a much higher share of their cash flow and payments relative to income grew much more significantly between 1980 and the Great Recession, compared with the NIPA outlay to disposable income measure. This difference 
relates closely to perspectives on household saving. The NIPA definition of the personal saving rate is simply one minus the NIPA outlay rate (see figure 7) and is plotted in figure 9. The middle line in figure 9 is our definition of adjusted gross household saving divided by adjusted disposable income. This measure includes accumulation of financial assets plus the gross investment in new owner-occupied housing. The bottom series in figure 9 is the adjusted financial saving rate. It corresponds to what most households would intuitively think of as saving: the accumulation of financial assets (or accumulation of debt if it is negative). This series is one minus the adjusted outlay rate plotted in figure 7.

The decline in the U.S. personal saving rate since the early 1980s has been a source of concern from a variety of perspectives for some time (see the discussion in Guidolin and La Jeunesse, 2007, for a clear survey). All three saving rate measures show this decline, but the decline is much sharper with the adjusted measures. It is also striking that the adjusted gross saving rate was negative from 1992 until the Great Recession, and the financial saving rate is usually negative, excessively so from the middle 1980s until 2008. The adjusted measures magnify the sense that household sector finances were on an unsustainable path prior to the Great Recession.

[Figure 9 Approximately Here]

As discussed previously, our adjusted cash flow measures of household disposable income exclude contributions to and capital returns on pension and retirement plans. Instead, we include pension benefits paid out as disposable income. Some of retirement plan contributions could sensibly be defined as household saving, particularly payments into $401 \mathrm{k}$ and $403 \mathrm{~b}$ plans (which we cannot fully separate from defined-benefit contributions in public NIPA data, as discussed earlier). Our treatment of pension and retirement fund activity reduces the overall 
saving rate. The difference between the NIPA personal saving rate and both of our adjusted household saving rates is larger in the high-inflation years due to higher nominal returns on assets in these plans. ${ }^{20}$ Therefore, if we were to include some retirement plan contributions in saving, the drop in the adjusted saving rates would be even larger than those shown in figure $9 .^{21}$

\section{Conclusion}

Two objectives motivate this study. First, we develop a consistent set of adjustments that improve the correspondence between aggregate measures of the household sector and widely used microeconomic surveys of households. Second, we propose measures of key aggregate household-sector variables that reflect actual cash flows that measure household demand and saving. The same adjustments to the NIPA household accounts are appropriate for both objectives.

With respect to our first objective, we judge the adjustments successful. We compare our adjusted aggregate income measure to three surveys, the CPS, the SCF, and the PSID. In all three cases, the adjusted measure was much closer to the level of income generated by aggregating the micro data with appropriate sample weights. While all three micro data sets show large shortfalls relative to the standard NIPA measures of income, the majority of the shortfall disappears in all three cases after the adjustments proposed here. In addition to looking at income, we also compared household expenditures derived from the PSID following the method described by

\footnotetext{
${ }^{20}$ As discussed by Perozek and Reinsdorf (2002) and Guidolin and La Jeunesse (2007), returns on assets that simply compensate for inflation should arguably be removed from saving. This adjustment would lower saving rates below what we report here.

${ }^{21}$ An additional measurement issue arises from corporate share buybacks as a means to distribute cash to the household sector. The proceeds from share repurchases are not included in NIPA disposable income or our adjusted household disposable income measures. Guidolin and La Jeunesse (2007) discuss how accounting for share buybacks raises both disposable income and saving. There are two measurement problems with making such an adjustment, however. First, there are no publicly available BEA data on share repurchases. Second, even if one gets data from other sources, there is no way to know what part of these cash flows goes to the household sector. We explored this issue with published repurchase data in Banyi et al. (2008) from 1985 to 2004. Including total share repurchases from this source as household income raises the financial saving rate somewhat, especially in the stock market boom years of the late 1990s. But the strong overall negative trend in adjusted saving over these years remains.
} 
Cooper (2010) and find that adjusted household outlays substantially matches the PSID expenditures data in levels, although the PSID measure fluctuates quite a bit and does not match either the standard NIPA measure or the adjusted measure in time-series volatility. In short, the NIPA household accounts differ conceptually from the data gathered by household surveys, and it is only natural that the resulting data differ substantially. By showing that a reconciliation of the underlying concepts substantially reduces the differences between the measures, we think we have provided reason for optimism about the validity of the micro data as a useful tool to disaggregate macro dynamics of the household sector, as long as the corresponding macro data are appropriately defined. ${ }^{22}$

With regard to our second objective, introducing an alternative perspective on the aggregate flows of the U.S. household sector, we believe that we have scored a second success. The adjusted measures correspond to a cash flow concept by removing large imputations that do not represent market transactions and do not create demand for market-produced goods and services. To the extent that important facts about the macro economy differ with the adjusted cash flow measures, we believe researchers, policy analysts, and forecasters should appreciate these differences. For example, it is only demand for market-produced consumption and new housing that motivates payroll employment.

Our results do indeed identify some important distinctions in the aggregate features of the U.S. household sector when income, consumption, household investment, and saving are adjusted to the cash flow micro concept. Recessions appear deeper over the entire sample period. Spending relative to income grows more prior to the Great Recession, and declines much more

\footnotetext{
${ }^{22}$ See Krimmel et al. (2013) for an example that involves adjusting the Federal Reserve Board's Flow of Funds Accounts (FFAs), the balance sheet counterpart to the NIPAs, to be comparable to the SCF, so that low-frequency share information from the latter could be combined with high-frequency, aggregate flow and revaluation data from the former.
} 
dramatically when the recession hits. The adjusted measures strengthen the case that household spending was the cause of this historic collapse.

Furthermore, the adjustments expose possible reasons for even greater concern about household saving than has already been voiced, as both measures of saving we develop decline much more than the standard NIPA personal saving rate. Our adjustments lead us to examine the conceptually appealing household financial saving measure, revealing the change in household financial net worth (excluding real assets and capital gains). We agree with Guidolin and La Jeunesse (2007) who analyze a variety of saving measures and conclude that because "the decline manifests itself in all standard measures ... the decline of the U.S. personal saving rate seems to be a real phenomenon worthy of further attention." From many perspectives, the trend of the U.S. household saving during the high-spending years of the Consumer Age was strongly negative, and the reversion of saving rates to more normal levels during the Great Recession was unprecedented over the span of our data.

We are not the only researchers taking another look at the national accounts in recent years. Notably, the Report by the Commission on the Measurement of Economic Performance and Social Progress (Stiglitz et al., 2012) suggests that GDP is not an ideal measure of social welfare and "the time is ripe for our measurement system to shift emphasis from measuring economic production to measuring people's well-being." Our contribution is consistent but less grand: we argue that when the national accounts are adjusted to a cash flow basis that does not try to measure well-being, it can do a better job of measuring the effect of the household sector on the aggregate economy. The cash flow concept also provide a much better link to microeconomic data which will help us better understand the aggregate implications of research that exploits household heterogeneity. 


\section{References}

Aguiar, Mark and Erik Hurst (2013) "Deconstructing Lifecycle Expenditure” Journal of Political Economy, forthcoming.

Bosworth, Barry P., Gary Burtless, and Sarah E. Anders (2007) "Capital Income Flows and the Relative Well-being of America’s Aged Population" Center for Retirement Research working paper 2007-21, December 2007.

Brown, Christopher. (2004) "Does Income Distribution Matter for Effective Demand? Evidence from the United States," Review of Political Economy, 16, 291-307.

Bureau of Economic Analysis (2007) "Measuring the Economy: A Primer on GDP and the National Income and Product Accounts," http://www.bea.gov/national/pdf/nipa_primer.pdf.

Bureau of Economic Analysis (2013) "A Guide to the National Income and Product Accounts," www.bea.gov/national/pdf/nipaguid.pdf.

Carroll, Christopher D. (2012) "Implications of Wealth Heterogeneity For Macroeconomics," http://www.econ2.jhu.edu/people/ccarroll/papers/W-Hetero-Fed/, May 20, 2012, .accessed December 11, 2013.

Congressional Budget Office (2013) "Individual Income Tax Receipts and the Individual Tax Base-February 2013 Baseline.” <http://www.cbo.gov/publication/43901>, accessed September 4, 2013.

Cooper, Daniel H. (2010) "Imputing Household Spending in the Panel Study of Income Dynamics: A Comparison of Approaches.” FRB Boston Working Paper Series no. 10-12.

Cynamon, Barry Z. and Steven M. Fazzari (2008) "Household Debt in the Consumer Age: Source of Growth—Risk of Collapse," Capitalism and Society, 3, 2, Article 3. 
and (2013) "Household Spending and Debt: Sources of Past Growth—Seeds of

Recent Collapse," in Cynamon, B.Z., S.M. Fazzari, and M. Setterfield, eds., After the Great Recession: The Struggle for Economic Recovery and Growth. New York: Cambridge University Press, chapter 6, 127-157.

Fixler, Dennis and David S. Johnson (2012) “Accounting for the Distribution of Income in the U.S. National Accounts," Paper prepared for the NBER Conference on Research in Income and Wealth "Measuring Economic Stability \& Progress Conference" September 30, 2012.

Gale, William G. and John Sabelhaus (1999) "Perspectives on the household saving rate," Brookings Papers on Economic Activity1999, no. 1: 181-224.

Heathcote, Jonathan, Fabrizio Perri, and Giovanni L. Violante (2010) "Unequal We Stand: An Empirical Analysis of Economic Inequality in the United States: 1967-2006" Review of Economic Dynamics, 13(1): 15-51.

Katz, Arnold J. (2012) "Explaining Long-term Differences between Census and BEA Measures of Household Income,” BEA Working paper: January, 2012.

King, Miriam, Steven Ruggles, J. Trent Alexander, Sarah Flood, Katie Genadek, Matthew B. Schroeder, Brandon Trampe, and Rebecca Vick. Integrated Public Use Microdata Series, Current Population Survey: Version 3.0. [Machine-readable database]. Minneapolis: University of Minnesota, 2010.

Krimmel, Jacob, Kevin B. Moore, John Sabelhaus, and Paul Smith (2013) "The Current State of U.S. Household Balance Sheets" Federal Reserve Bank of St. Louis Review, September/October, 95(5): 337-59. 
Guidolin, Massimo and Elizabeth A. La Jeunesse (2007) “The Decline in the U.S. Personal Saving Rate: Is It Real and Is It a Puzzle?” Federal Reserve Bank of St. Louis Review, 89(6), 491-514.

Laitner, John and Dan Silverman, (2005) "Estimating Life-Cycle Parameters from Consumption Behavior at Retirement” NBER Working Papers 11163.

Palley, Thomas I. 2002. "Economic Contradictions Coming Home to Roost? Does the U.S. Economy Face a Long-Term Aggregate Demand Generation Problem?” Journal of Post Keynesian Economics, 25 (fall), 10-32.

Perozek, Maria G. and Marshall B. Reinsdorf (2002) "Alternative Measures of Personal Saving," Survey of Current Business, 82(4), 13-24.

Ruser, John, Adrienne Pilot, and Charles Nelson (2004) “Alternative Measures of Household Income: BEA Personal Income, CPS Money Income, and Beyond,” Prepared for presentation to the Federal Economic Statistics Advisory Committee on December 14, 2004. Sabelhaus, John, David Johnson, Stephen Ash, David Swanson, Thesia Garner, John Greenlees, and Steve Henderson (2013) "Is the Consumer Expenditure Survey Representative by Income?," in Improving the Measurement of Consumer Expenditures, University of Chicago Press.

Slesnick, Daniel T. (1992) “Aggregate Consumption and Saving in the United States” Review of Economics and Statistics, 74, 585-597.

Stiglitz, Joseph E., Amartya Sen, and Jean-Paul Fitoussi (2009) Report by the Commission on the Measurement of Economic Performance and Social Progress. United Nations Press.

van Treeck, Till and Simon Sturn (2012) 'Income Inequality as a Cause of the Great Recession? A Survey of Current Debates," International Labour Organization working paper (April). 
Figure 4. NIPA Personal Outlays Compared to PSID Outlays

(per capita, real; NIPA measures in gray, adjusted measures in red, and aggregated micro data in blue)

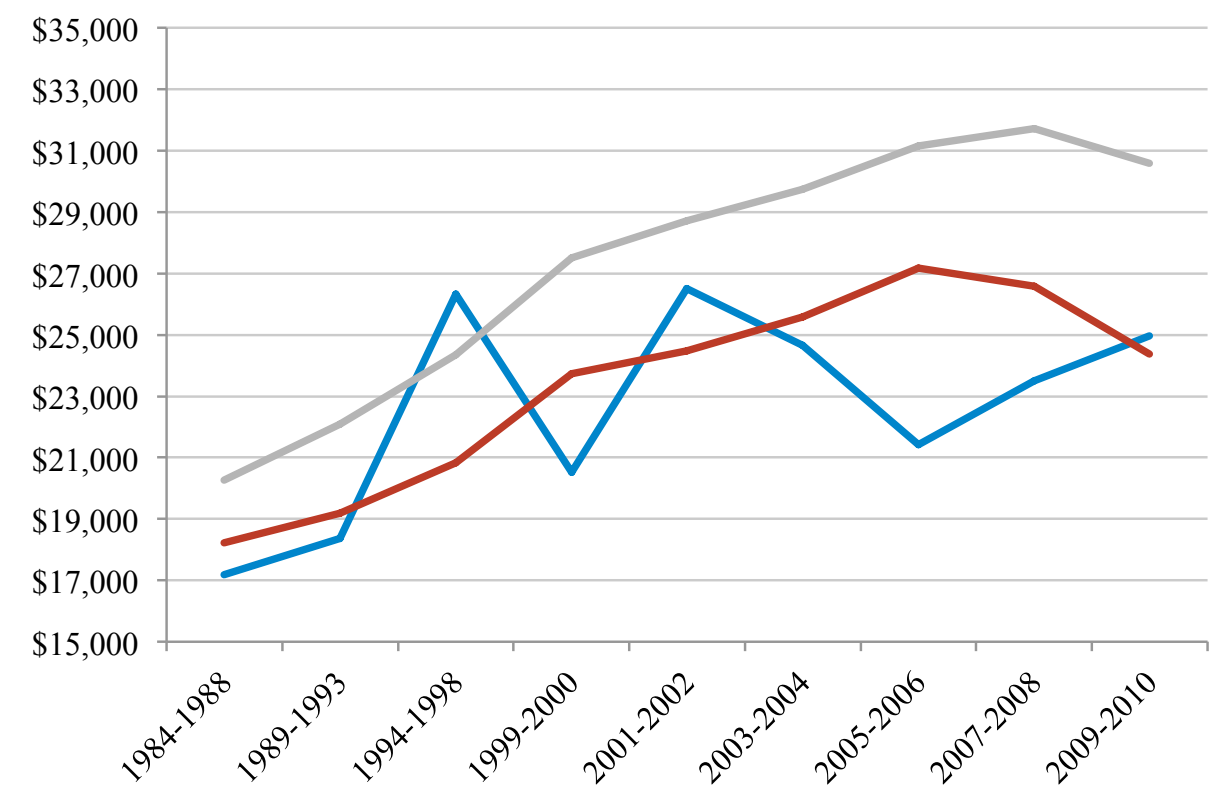

Figure 5. NIPA PCE to NIPA Disposable Personal Income and Household Demand to Adjusted Household Disposable Income

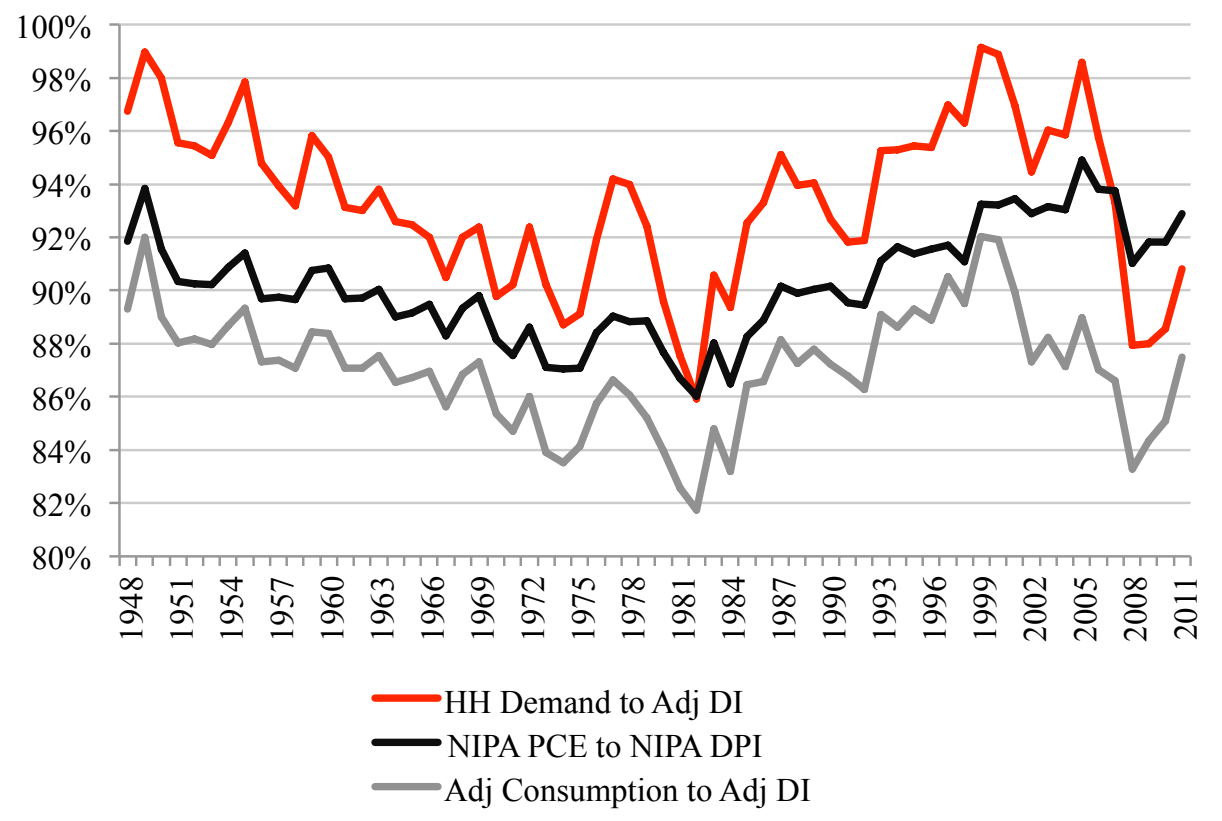


Figure 6. NIPA PCE over GDP, Household Demand Plus Healthcare Spending on behalf of Households over Adjusted GDP, and Household Demand over Adjusted GDP

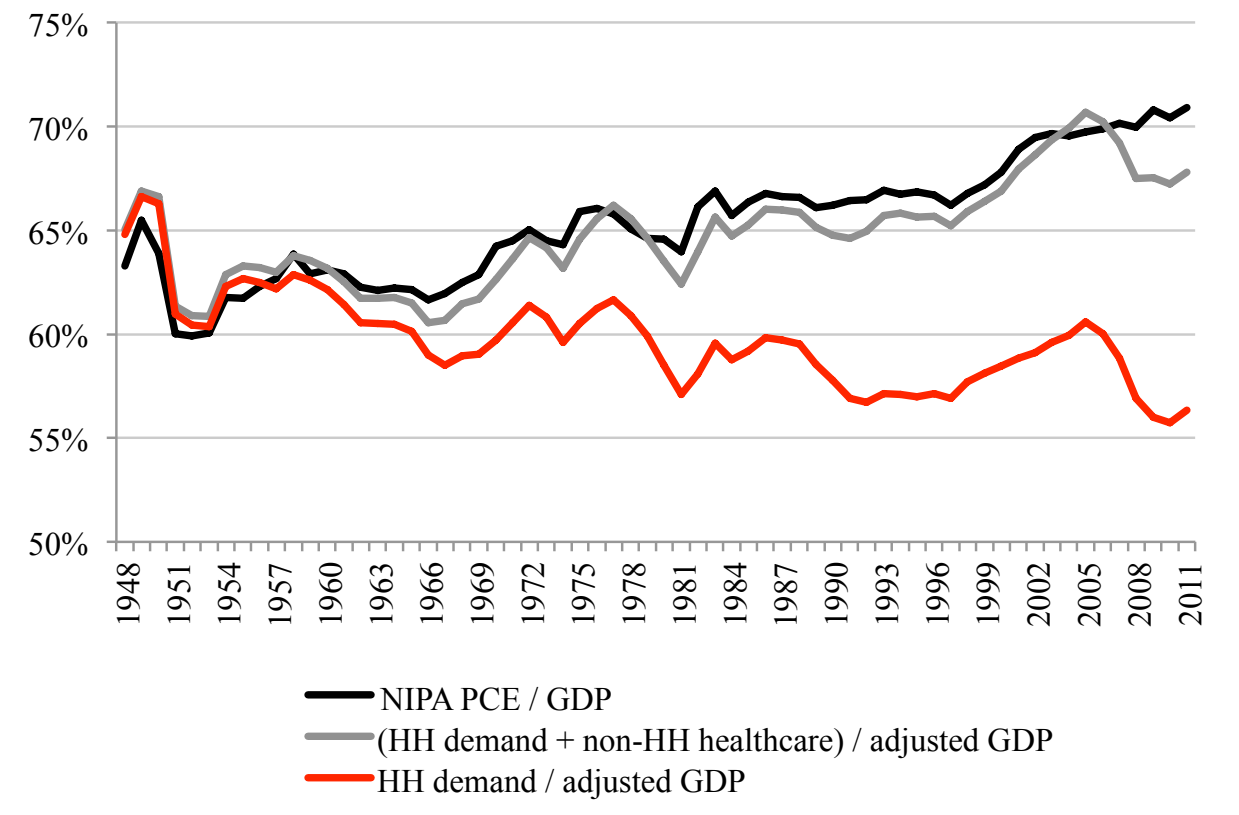

Figure 7. NIPA Personal Outlays to NIPA Disposable Personal Income and Adjusted Outlays to Adjusted Household Disposable Income

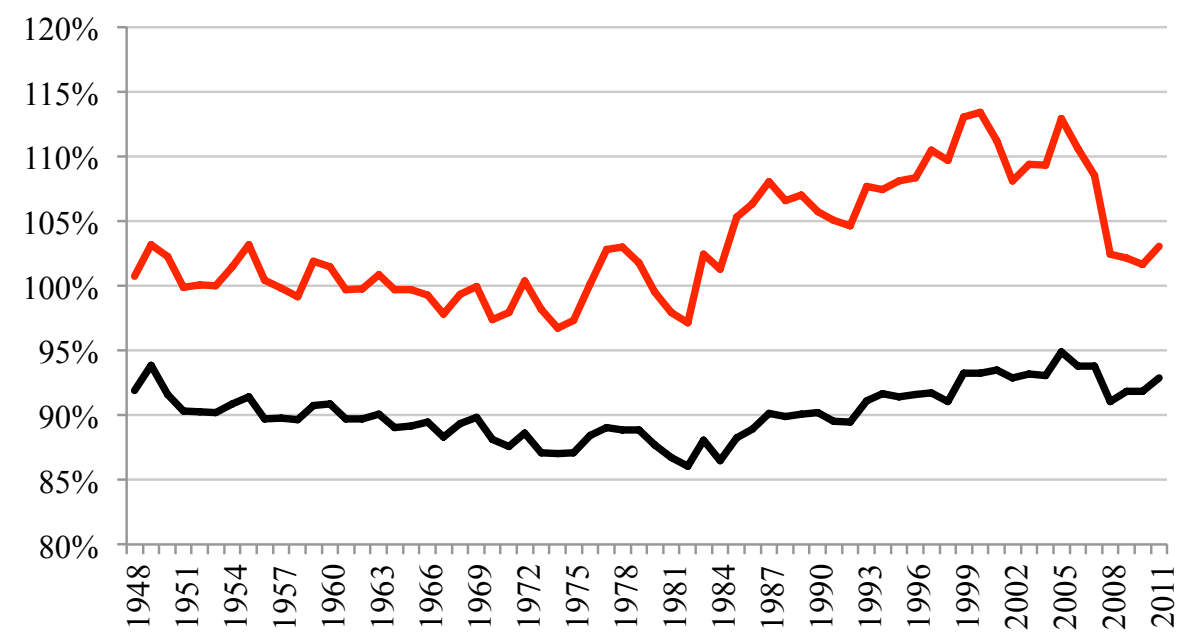

HH Demand to Adj DI

NIPA PCE to NIPA DPI 
Figure 8. Three Components of Adjusted Transfers as Percentages of Adjusted Disposable Income (mortgage interest shown in red, personal interest shown in black, and personal transfers shown in gray)

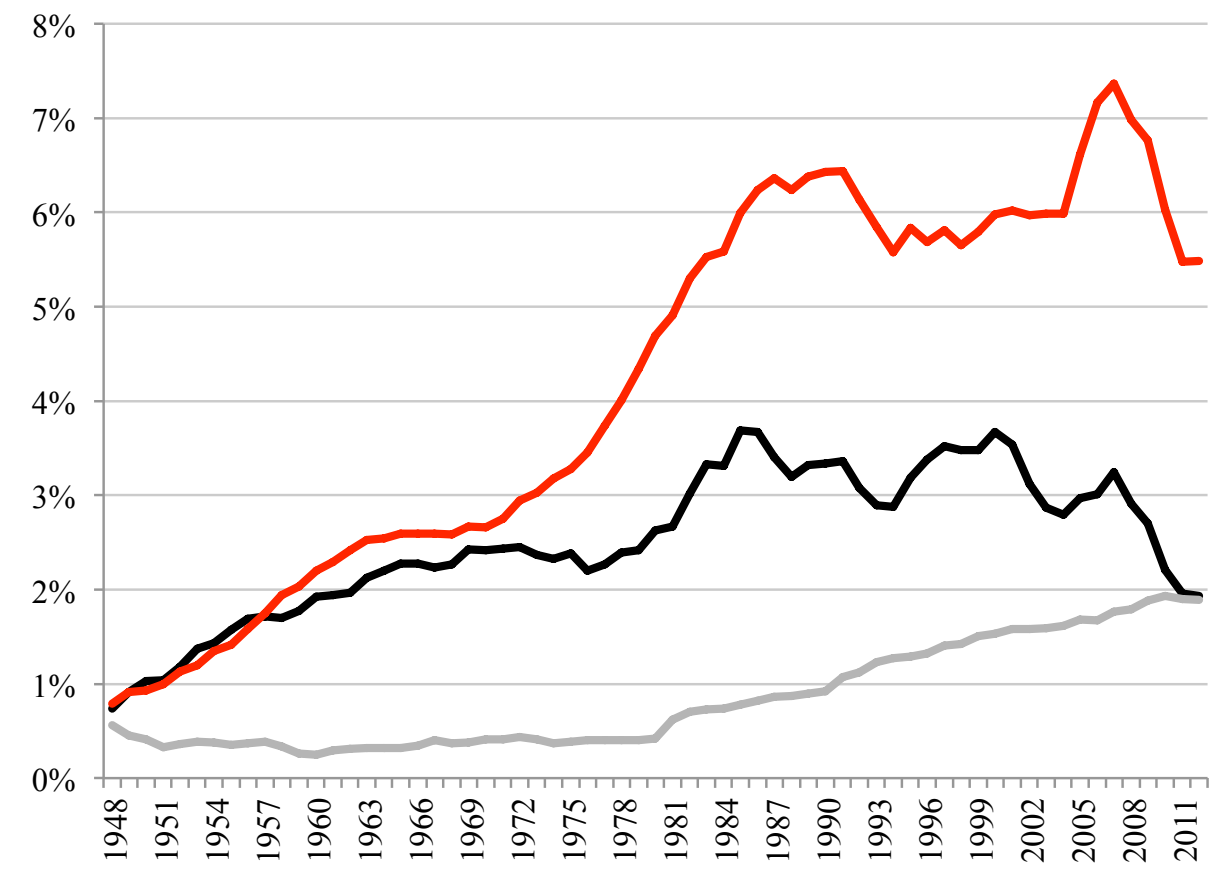

Figure 9. NIPA and Adjusted Measures of Saving as a Portion of Disposable Income

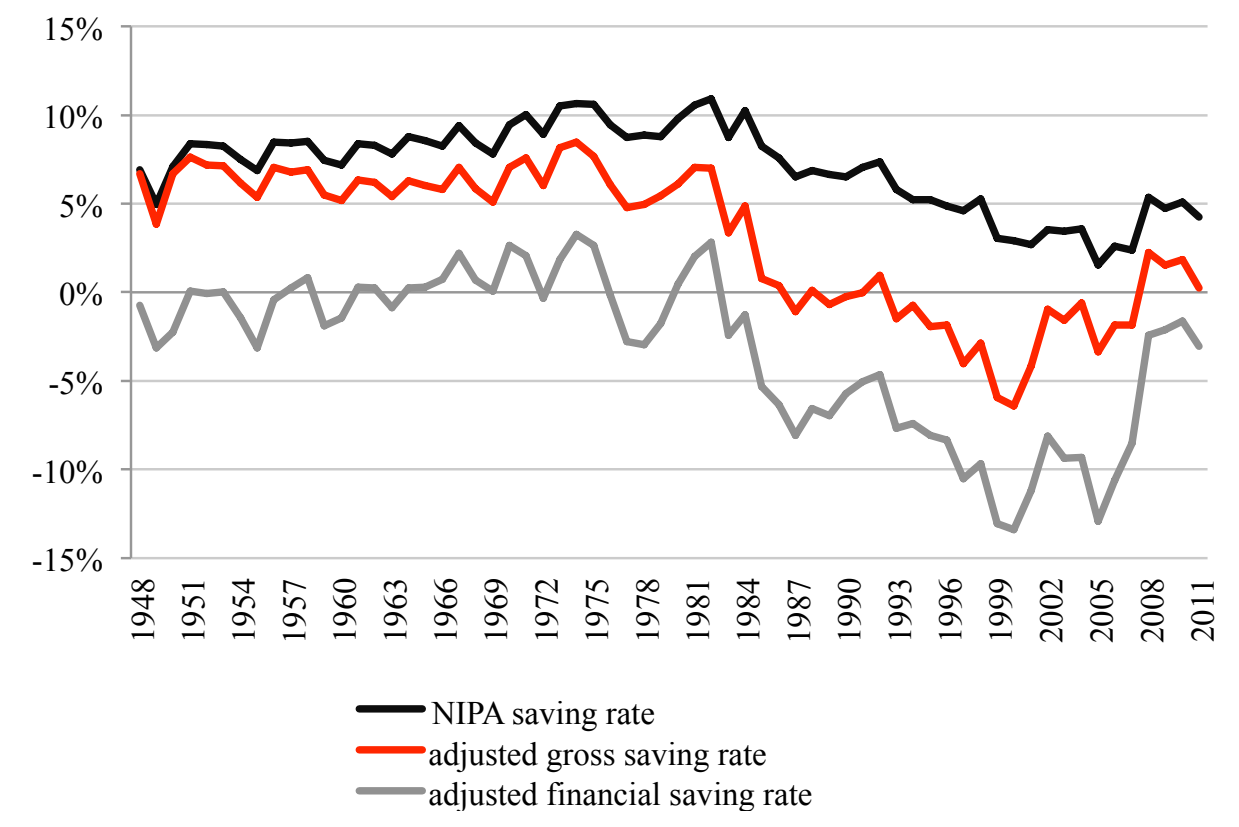


Table 1 (Part A): Adjustments to NIPA Data

\begin{tabular}{|c|c|c|c|c|c|c|c|c|}
\hline Original NIPA Data & $\begin{array}{l}\text { NIPA Table / } \\
\text { Line for } \\
\text { Source Data } \\
(1)\end{array}$ & $\begin{array}{l}\text { Disposable } \\
\text { Personal } \\
\text { Income }\end{array}$ & $\begin{array}{c}\text { Personal } \\
\text { Consumption } \\
\text { Expenditures }\end{array}$ & $\begin{array}{l}\text { Household } \\
\text { Investment }\end{array}$ & $\begin{array}{l}\text { Personal } \\
\text { Interest } \\
\text { and } \\
\text { Transfers }\end{array}$ & $\begin{array}{l}\text { Financial } \\
\text { Saving }\end{array}$ & $\begin{array}{l}\text { Other } \\
\text { Demand }\end{array}$ & $\begin{array}{c}2011 \\
\text { Amount } \\
\text { (\$ Bill.) }\end{array}$ \\
\hline \multicolumn{9}{|c|}{ 1. Adjustments for Owner-Occupied Homes } \\
\hline 1a. Implicit rent (2) & $7.12 / 133$ & - & - & & & & & 1235.8 \\
\hline 1b. Intermediate inputs & $7.12 / 134$ & + & + & & & & & 197.1 \\
\hline 1c. Mortgage Interest & $7.12 / 186$ & + & & & + & & & 469.2 \\
\hline 1d. Depreciation (3) & $7.12 / 140$ & + & & & & + & & 209.5 \\
\hline $\begin{array}{l}\text { 1e. Construction of Single- } \\
\text { Family Structures (4) }\end{array}$ & $7.12 / 177$ & & & + & & - & & 282.5 \\
\hline \multicolumn{9}{|c|}{ 2. Imputed Value of Free Financial Services } \\
\hline $\begin{array}{l}\text { 2a. Imputed interest } \\
\text { received by households }\end{array}$ & $7.11 / 61$ & - & & & & - & & 456.1 \\
\hline 2b. Depositors (5) & $7.12 / 147$ & & - & & & + & & 204.1 \\
\hline 2c. Borrowers & $7.12 / 152$ & & - & & & + & & 51.1 \\
\hline \multicolumn{9}{|c|}{ 3. Pension Plan and Retirement Saving Adjustments } \\
\hline 3a. Employer Contributions & $6.11 / 23$ & - & & & & - & & 505.7 \\
\hline $\begin{array}{l}\text { 3b. Gov. Employee } \\
\text { Contributions }\end{array}$ & $6.11 / 50$ & - & & & & - & & 59.9 \\
\hline $\begin{array}{l}\text { 3c. Estimated Private } \\
\text { Employee Contributions }\end{array}$ & (6) & - & & & & - & & 65.6 \\
\hline $\begin{array}{l}\text { 3d. Pension fund capital } \\
\text { income }\end{array}$ & (7) & - & & & & - & & 507.0 \\
\hline 3e. Benefits Paid & $6.11 / 38$ & + & & & & + & & 820.2 \\
\hline \multicolumn{9}{|c|}{ 4. Workers' Compensation } \\
\hline $\begin{array}{l}\text { 4a. Premiums paid by } \\
\text { employers }\end{array}$ & $6.11 / 35$ & - & & & & - & & 48.8 \\
\hline $\begin{array}{l}\text { 4b. Benefits received by } \\
\text { Workers }\end{array}$ & $6.11 / 48$ & + & & & & + & & 43.8 \\
\hline
\end{tabular}


Table 1 (Part B): Adjustments to NIPA Data

\begin{tabular}{|c|c|c|c|c|c|c|c|c|}
\hline & $\begin{array}{l}\text { NIPA Table / } \\
\text { Line for } \\
\text { Source Data }\end{array}$ & $\begin{array}{l}\text { Disposable } \\
\text { Personal } \\
\text { Income }\end{array}$ & $\begin{array}{c}\text { Personal } \\
\text { Consumption } \\
\text { Expenditures }\end{array}$ & $\begin{array}{l}\text { Household } \\
\text { Investment }\end{array}$ & $\begin{array}{l}\text { Personal } \\
\text { Interest } \\
\text { and } \\
\text { Transfers }\end{array}$ & $\begin{array}{c}\text { Personal } \\
\text { Financial } \\
\text { Saving }\end{array}$ & $\begin{array}{c}\text { Other } \\
\text { Demand }\end{array}$ & $\begin{array}{c}2011 \\
\text { Amount } \\
\text { (\$ Bill.) }\end{array}$ \\
\hline \multicolumn{9}{|c|}{ 5. Adjustments for Medical Insurance } \\
\hline $\begin{array}{l}\text { 5a. Group insurance } \\
\text { purchased by employers }\end{array}$ & $6.11 / 32$ & - & - & & & & + & 602.3 \\
\hline 5b. Medicare & $3.12 / 6$ & - & - & & & & + & 545.1 \\
\hline 5c. Medicaid & $3.12 / 32$ & - & - & & & & + & 418.3 \\
\hline 5d. Military medical & $3.12 / 16$ & - & - & & & & + & 4.4 \\
\hline \multicolumn{9}{|c|}{ 6. Remove Activities of Non-Profit Institutions } \\
\hline 6a.Rental income & $2.9 / 48$ & - & & & & - & & 7.6 \\
\hline 6b. Interest income & $2.9 / 50$ & - & & & & - & & 32.4 \\
\hline 6c. Dividend income & $2.9 / 51$ & - & & & & - & & 20.3 \\
\hline $\begin{array}{l}\text { 6d. Implicit rental value of } \\
\text { non-profit fixed assets }\end{array}$ & $7.12 / 141$ & - & - & & & & & 104.8 \\
\hline $\begin{array}{l}\text { 6e. Transfers from } \\
\text { governments to non-profits }\end{array}$ & $2.9 / 53$ & - & & & & - & & 24.2 \\
\hline $\begin{array}{l}\text { 6f. Transfers from business } \\
\text { to non-profits }\end{array}$ & $2.9 / 54$ & - & & & & - & & 16.1 \\
\hline $\begin{array}{l}\text { 6g. Transfers from } \\
\text { households to non-profits }\end{array}$ & $2.9 / 55$ & & & & + & - & & 241.8 \\
\hline $\begin{array}{l}\text { 6h. Transfers from non- } \\
\text { profits to households }\end{array}$ & $2.9 / 32$ & + & & & & + & & 84.1 \\
\hline $\begin{array}{l}\text { 6i. Consumption of non- } \\
\text { profits in PCE }\end{array}$ & $2.9 / 57$ & & - & & & + & + & 291.9 \\
\hline
\end{tabular}


Table 1 (Part C): Adjustments to NIPA Data

\begin{tabular}{|c|c|c|c|c|c|c|c|c|}
\hline & $\begin{array}{l}\text { NIPA Table / } \\
\text { Line for } \\
\text { Source Data }\end{array}$ & $\begin{array}{l}\text { Disposable } \\
\text { Personal } \\
\text { Income }\end{array}$ & $\begin{array}{c}\text { Personal } \\
\text { Consumption } \\
\text { Expenditures }\end{array}$ & $\begin{array}{l}\text { Household } \\
\text { Investment }\end{array}$ & $\begin{array}{l}\text { Personal } \\
\text { Interest } \\
\text { and } \\
\text { Transfers }\end{array}$ & $\begin{array}{l}\text { Personal } \\
\text { Financial } \\
\text { Saving }\end{array}$ & $\begin{array}{l}\text { Other } \\
\text { Demand }\end{array}$ & $\begin{array}{l}2011 \\
\text { Amount } \\
\text { (\$ Bill.) }\end{array}$ \\
\hline \multicolumn{9}{|c|}{ 7. Miscellaneous Adjustments } \\
\hline \multicolumn{9}{|c|}{ Eliminate consumption in kind } \\
\hline $\begin{array}{l}\text { 7a. Farm products } \\
\text { consumed on farms }\end{array}$ & $7.12 / 167$ & - & - & & & & & 0.1 \\
\hline $\begin{array}{l}\text { 7b. Food furnished to } \\
\text { employees }\end{array}$ & $7.12 / 171$ & - & - & & & & & 15.8 \\
\hline 7c. Military clothing & $7.12 / 172$ & - & - & & & & & 0.4 \\
\hline 7d. Employee lodging & $7.12 / 173$ & - & - & & & & & 0.6 \\
\hline \multicolumn{9}{|c|}{ Technical Adjustments to Proprietors' Income } \\
\hline $\begin{array}{l}7 \mathrm{f} \text {. Inventory valuation } \\
\text { adjustment }\end{array}$ & $1.12 / 36$ & - & & & & - & & -8.9 \\
\hline $\begin{array}{l}\text { 7g. Capital consumption } \\
\text { allowance }\end{array}$ & $1.12 / 37$ & - & & & & - & & 209.0 \\
\hline $\begin{array}{l}\text { 7h. Capital consumption } \\
\text { allowance for farms }\end{array}$ & $1.12 / 33$ & - & & & & - & & -5.9 \\
\hline $\begin{array}{l}\text { 7i. Margins on owner-built } \\
\text { housing }\end{array}$ & $7.12 / 179$ & - & & & & - & & 0.6 \\
\hline \multicolumn{9}{|l|}{ Subsidies and Related Items } \\
\hline $\begin{array}{l}7 \mathrm{j} . \text { Employer supplements } \\
\text { for property / casualty } \\
\text { insurance }\end{array}$ & $7.12 / 160$ & - & - & & & & + & 7.5 \\
\hline 7k. Rental subsidies & $7.12 / 136$ & - & & & & - & & 1.0 \\
\hline 71. Energy assistance & $3.12 / 38$ & - & - & & & & + & 4.8 \\
\hline \multirow[t]{2}{*}{ Adjusted Data (8) } & & $\begin{array}{l}\text { Adjusted } \\
\text { Disposable } \\
\text { Income } \\
\end{array}$ & $\begin{array}{c}\text { Adjusted } \\
\text { Consumption }\end{array}$ & $\begin{array}{l}\text { Household } \\
\text { Investment }\end{array}$ & $\begin{array}{l}\text { Adjusted } \\
\text { Transfers }\end{array}$ & $\begin{array}{l}\text { Financial } \\
\text { Saving }\end{array}$ & $\begin{array}{c}\text { Other } \\
\text { Demand }\end{array}$ & \\
\hline & & $8,513.3$ & $7,449.0$ & 282.2 & 1,041.8 & -187.1 & $1,874.3$ & \\
\hline
\end{tabular}




\section{Notes to Accompany Table 1}

(1) The aggregate NIPA data are obtained from table 2.1 lines 27 (disposable personal income), 29 (personal consumption expenditures), 30 (personal interest), 31 (personal transfers), and 34 (personal saving).

(2) The adjustments to remove imputed items for owner-occupied housing are taken from NIPA table 7.12 ("Imputations in the National Income and Product Accounts") because all items in this table are broken out for owner-occupied housing. The concepts, however, are easier to understand from the structure of NIPA table 7.4.5 ("Housing Sector Output, Gross Value Added, and Net Value Added") although all some items in this table do not split owner-occupied homes out from the total housing sector.

(3) Because we start from the NIPA components and adjust from there, the saving component we start with has net residential investment in it. Since we want financial saving to measure changes in financial assets and liabilities, we add depreciation back into financial saving (because it is not a transaction-based change), but then we subtract the entirety of gross residential investment out from financial saving (because it is saving in the form of a real asset and necessarily a reduction in financial net worth).

(4) Includes value of improvements to owner-occupied homes and broker commission for the sale of owner-occupied homes.

(5) The imputed value of free financial services is included in the NIPA definition of personal income (line 1 of table 2.1).

(6) Employee contributions to private pension and retirement plans estimated as the ratio of government employee contributions to pension plans to government employer contributions (line 50 divided by line 27 of NIPA table 6.11) multiplied by employer contributions to private pension and profit-sharing plans (line 24 of table 6.11).

(7) Following Katz (2012), we estimated the income on pension reserves by applying the rate of return earned on life insurance reserves (NIPA table 7.11, line 46 divided by Flow of Funds Z1 Table 115, line 1) to the pension reserves (sum of line 1 from Flow of Funds Z1 tables L.116, L.117, L.118).

(8) Household demand equals adjusted consumption plus household investment, or \$7,731.2 billion in 2011. Adjusted outlays equals household demand plus adjusted transfers, or $\$ 8,773.0$ billion in 2011. Adjusted gross saving equals financial saving plus household investment, or $\$ 95.1$ billion in 2011 . 
Figure 1. Per Capita NIPA Personal Income and Expenditure and Adjusted Household Income and Expenditure

\section{A. Disposable Income}

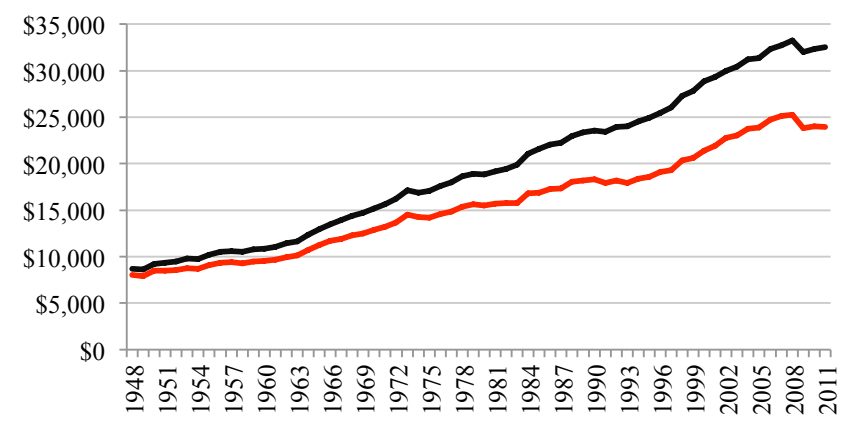

per capita real NIPA DPI

per capita real adjusted DPI

C. Consumption Expenditures

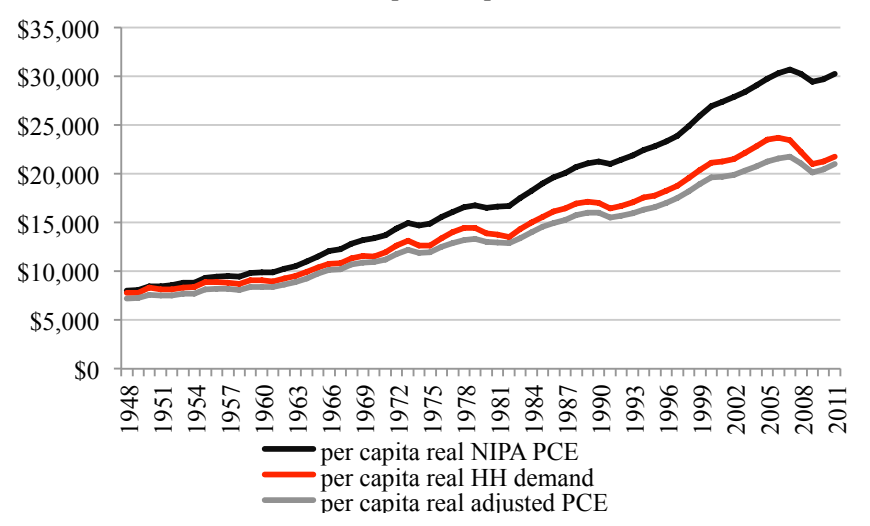

\section{B. Transfers}

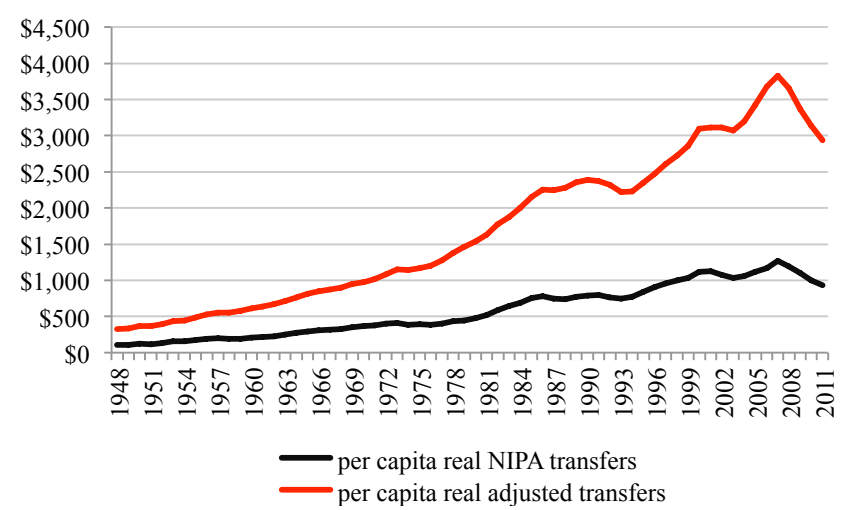

D. Saving

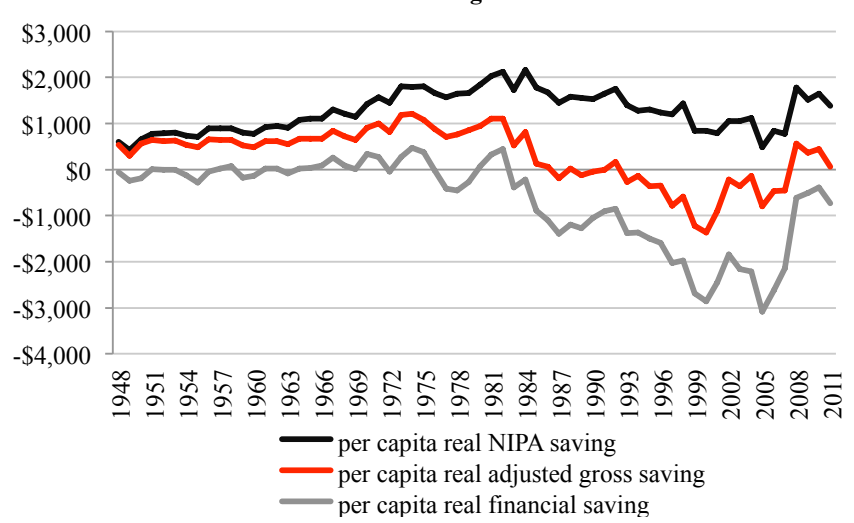


Figure 2. Ratio of Single-family Residential Construction to Imputed Homeowner Rent Net of Intermediate Goods

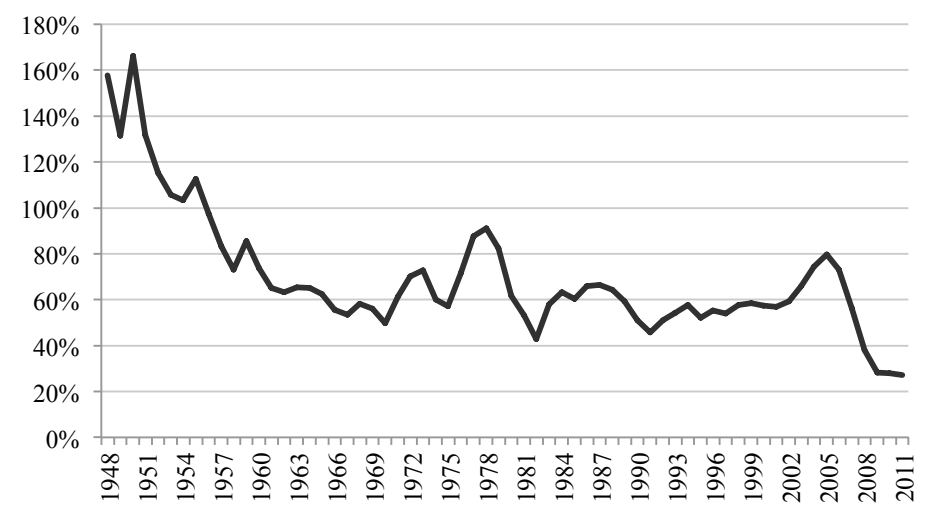

\footnotetext{
ratio of owner-occupant residential construction to imputed rent on owner-occupied housing net of intermediate inputs
} 
Figure 3. NIPA Personal Income Compared to CPS, SCF, and PSID Income; NIPA Personal Outlays Compared to PSID Outlays (per capita, real; NIPA measures in gray, adjusted measures in red, and aggregated micro data in blue)

A. CPS Money Income vs. NIPA Personal Income

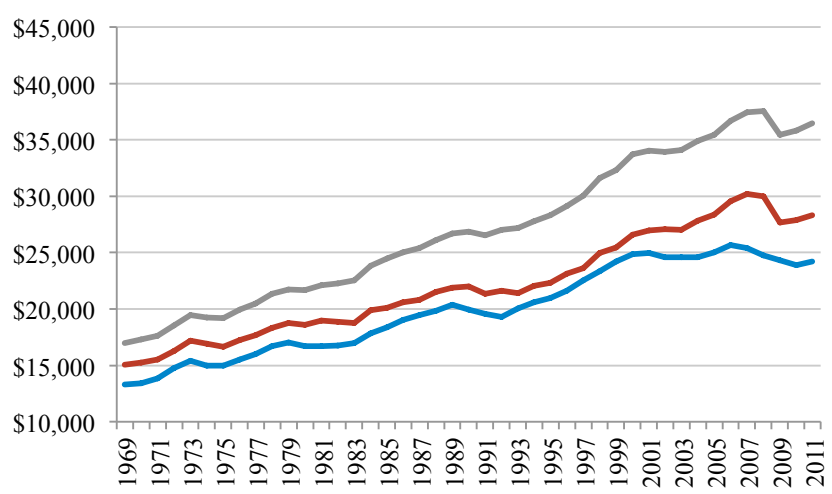

C. PSID Income vs. NIPA Personal Income (plus capital gains)

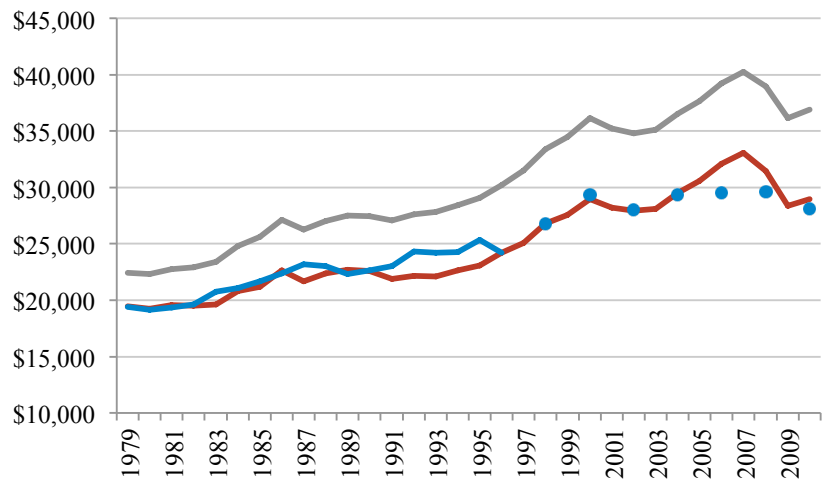

B. SCF Income vs. NIPA Personal Income (plus capital gains)

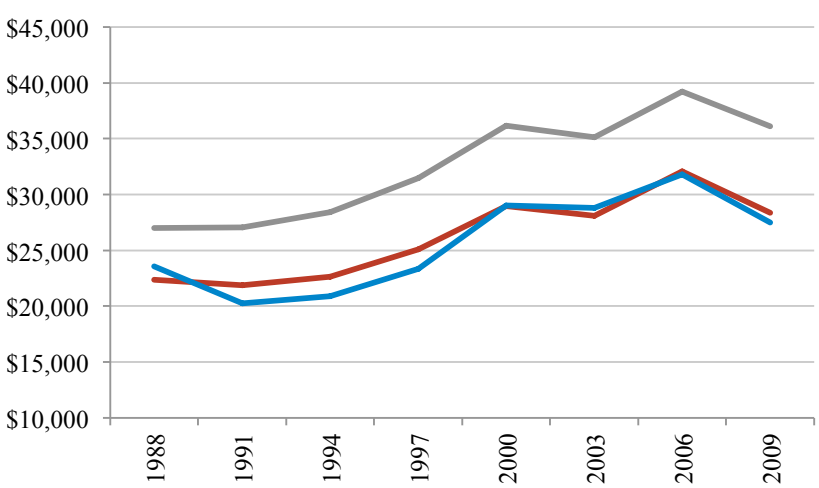

